\title{
13. \\ INTELEKTUALAC PRED OGLEDALOM: \\ RASPRAVA O INTELEKTUALCIMA \\ DANAS
}

\section{Filip Šimetin Šegvić i Nikolina Šimetin Šegvić}

UDK: 316.344.32(091)

Sažetak: Ovaj tekst dio je rasprave o temi intelektualac danas, njegovu položaju i ulozi. Rasprava pozicionira današnjeg intelektualca u odnosu na one s kraja 19. stoljeća i tijekom 20. stoljeća, pokušavajući ga analizirati i okarakterizirati. Također, iznose se razmišljanja o poteškoćama, izazovima i pitanjima s kojima se intelektualac suočava. Tomu se suprotstavljaju očekivanja društva i (ne)razumijevanje problematike, uglavnom svedeno na pitanje o korisnosti intelektualca. Propituju se i uspoređuju razni modeli shvaćanja intelekta i intelektualca te njegove prezentacije u kontekstu rasprave o nestanku intelektualaca. U prilogu članku nalaze se razgovori s inozemnim znanstvenicima, stručnjacima, umjetnicima - naposljetku, intelektualcima - o određenim pitanjima koja se najčešće povezuju s proučavanom problematikom.

Ključne riječi: intelektualac, mediji, promjena, računalo, društvo, razgovor

\section{Slika prva:}

Dodiže se teški zastor zagasite boje. Pojavljuje se omanji ozbiljni čovjek kratka koraka.

Sivo, uredno odijelo i tamna kravata, lagane okrugle naočale koje prate guste obrve i

oštre crte obla lica. Blaga, ali česta gestikulacija, jasan i prodoran pogled samo bi na trenutak otkrivali bljedunjavo lice, unutarnju uznemirenost i bojažljivost koju je pred kamerom uspješno nadilazio sredovječni oksfordski gospodin. Nakon kratke pauze staloženi glas tog oksfordskog gospodina najavljuje temu; pažnja se u potpunosti okreće njemu. $\mathrm{O}$ čemu se radi? Objašnjenje slijedi.

\section{Prije toga, slika druga:}

Izmjenjuju se kadrovi. Kamera pokazuje paralelne prikaze. Na jednoj strani mirna i staložena, u sebe vjerojatno pretjerano sigurna voditeljica. Na drugoj strani također miran čovjek u ranim četrdesetim godinama koji se uživo uključuje u prijenos. Vrijeme prolazi, osmijeh se pretvara u grč. Jakost glasa ostaje jednaka, mijenja se boja. 
Sada obećano pojašnjenje: intelektualac nekad, intelektualac danas. Moglo bi se reći - intelektualac u spirali. Prva slika opisuje nam poznatog britanskog povjesničara Alana Taylora pred TV kamerama na "Challengeu" 1957. godine. Taj televizijski challenge, dakle "izazov", nastao je na temelju jednostavnog, ali provokativnog upita: može li stručnjak, u ovome slučaju povjesničar, održati pozornost televizijske publike unutar 30 minuta svojega izlaganja. Eksperiment je uspio. A. J. P. Taylor, čovjek koji je jednom prilikom nakon novinskog intervjua izjavio: "After you have lived with books as long as I have, you start preferring them to people" - podsjećajući kako je za klasičnog intelektualca medij knjige, pisanja, najbliži oblik socijalizacije - izronio je iz mora britanskih povjesničara kao velika televizijska zvijezda, kao intelektualac par excellence. U narednim desetljećima uslijedili su deseci i stotine nastupa, izjava i komentara, priloga i emisija, koji su zajedno pokrili neizbrojivu količinu aktualnih ili povijesnih tema. Tragovi nelagode potpuno su nestali. Naočale su postale oštrije, kravatu je zamijenila leptir-mašna. Knjige tog povjesničara prodavale su se sve brže, sve ga se više tražilo. Rođena je zvijezda, nastao je model: uspješan intelektualac, uglađen gospodin, svojom je jezgrovitošću i jasnim jezičnim izražajem osvojio publiku, popularizirajući znanost, približavajući BBC-jevim gledateljima kontroverze i teorije, teze i rasprave. U filmu Monty Python i sveti gral 1970-ih pojavljuje se moderni povjesničar-intelektualac, načinjen prema taylorovskom modelu. Taj se model vrlo brzo počeo pojavljivati diljem svijeta. Sjetit ćemo se tako i nastupa hrvatskoga povjesničara umjetnosti Radovana Ivančevića. Na BBC-ju danas gledamo nastavak takva modela u povjesničaru Simonu Schami.

Druga slika opisuje nam posve različitu, iako ne u potpunosti suprotnu, situaciju iz srpnja 2013. godine. Reza Aslan, sveučilišni profesor na Riversideu, predavač kreativnog pisanja i religijski stručnjak, pozvan je na američki FOX da kao autor predstavi svoju novu knjigu Zealot: The Life and Time of Jesus of Nazareth. ${ }^{2}$ Knjiga je i prije izazvala burne reakcije: Aslan, porijeklom iz Irana, prešao je na evangelizam s 15 godina, da bi se nekoliko godina potom ponovno konvertirao na islam. Voditeljica razgovora nije mogla nadići tu činjenicu, konstantno ističući da je musliman napisao knjigu o Isusu, nikako ne prelazeći na drugu temu. Aslan se branio naglašavajući svoju stručnost i školovanost, svoje znanje povijesti religije, doktorate. Voditeljica je ponavljala: "Ali zašto ste kao musliman odlučili pisati knjigu o Isusu...?”

Razlike u kontekstu, 1950-e naspram 2010-ih, BBC naspram FOX Newsa, podučavanje naspram senzacionalizma, goleme su. Međutim, ne smije umaknuti zapaziti i suštinske razlike u shvaćanju intelektualca i njegove djelatnosti. Drugi nam primjer svjedoči promjenu. Radi se o krajnostima koje se jasno ocrtavaju: s jedne strane potpuno neshvaćanje intelektualca, obezvređivanje njegova djela i rada, besmislena simplifikacija njegova istraživanja. $S$ druge strane senzacionalizam, vrijedni "screen time", skandal koji potiče prodaju knjige, bijeg u stručnost i nabrajanje titula. Iako su mediji jednoobrazno zaključili da je voditeljica skandalozno nastupala u razgovoru, osudili čitav intervju i proglasili ga "najvećom sramotom FOX Newsa" koja je dosegla razinu neugode dotad viđenu samo u seriji "Bez oduševljenja, molim" i britanskom originalu "U uredu", ${ }^{3}$ nakon nekoliko tjedana počelo se

\footnotetext{
Ved Parkash Menta, The Fly and the Fly-Bottle: Encounters with British Intellectuals, London 1961., 147.

2 Kod nas je u međuvremenu knjiga prevedena i dostupna pod naslovom: Zelot: Život i vrijeme Isusa iz Nazareta, Zagreb 2013.

3 Mary Elizabeth Williams, "The Reza Aslan interview reveals our collective ignorance" (http://www.salon. com/2013/07/30/the_reza_aslan_interview_reveals_our_collective_ignorance/); Matilda BATTERSBY, "Most em-
} 
raspravljati i o upitnoj stručnosti Aslana, koji je, braneći se impresivnim kurikulumom, tu impresivnost znatno pojačao.

Čemu tolika pažnja televiziji i medijima? Donedavno je televizija nemilosrdno razabirala "prave" od "lažnih" ili "nezanimljivih" intelektualaca, bila je arbitar mode, odlučivala o stručnosti, opredjeljenju ili poziciji intelektualca. Samo donedavno, jer novi medij interneta, sa svojim blogovima i domenama, ponešto je izmijenio situaciju: za neke ju je pogoršao, za neke poboljšao.

Odnos s medijem televizije mijenjao se, kako nam opisane slike svjedoče: u počecima je intelektualac taylorovski nastojao ovladati televizijom. Netko s manje, netko s više uspjeha. No, u jednom - vrlo dugom - trenutku intelektualac je posustao i dopustio da televizija ovlada njime. Angažman koji je intelektualac pomoću televizije želio pokazati i dokazati, vratio se poput bumeranga. Pogodio ga je medijski instant-angažman, u korist vlastite promocije. Pierre Bourdieu objašnjava to vrlo jasno: stručnjak koji je angažiran u vlastitoj struci i svoj posao radi uspješno, zadovoljan je i teže inklinira stalnim medijskim nastupima. Stručnjak koji, međutim, nije uspješan ili se ne može zadovoljiti uspjesima u vlastitoj struci, nedostatak afirmiranosti traži afirmacijom na drugome području, najčešće u svijetu medija, kojega su se "zadovoljni" odrekli. ${ }^{4} S$ druge su strane akademski intelektualci, dakle stručnjaci na svojemu području, koji su uslijed strukturnih institucijskih promjena na sveučilištima i istraživačkim institutima prihvatili ulogu usko specijaliziranih stručnjaka, udaljavajući se svjesno od javne sfere, zatvarajući se u svijet stručnog žargona i akademskih učionica. Dominacija tzv. "field" ili "area studies", segmentiranost znanstvene zajednice zatvorene u kampuse s desecima i stotinama odjela ili odsjeka, sa stručnjacima za ograničena područja ili razdoblja, ličnosti ili probleme, teorije ili teze, obuhvatila je u velikoj mjeri humaniste i akademske intelektualce. $\mathrm{Na}$ taj je način intelektualac razgraničen, njegov je prostor sužen: djeluje ili javno ili akademski, a vrlo rijetko na oba područja s jednakom učinkovitošću. Sveden je na jedan, dva ili eventualno nekoliko problema o kojima "treba" ili "može" govoriti. Može li se krivnja prebaciti na javne intelektualce koji su dio akademskoga svijeta? Tko polaže pravo na to? Amitai Etzioni, američko-izraelski sociolog i politolog, ustvrdio je da je u javnosti jednostavnije hrabro progovoriti o određenoj temi i problemu ako iza pojedinca stoji već siguran posao ili institucija, u njegovu slučaju akademska karijera redovnog profesora. ${ }^{5}$ Dakle, poput Damoklova mača, situacija akademski osiguranog intelektualca otvara mu mnoga vrata i daje sigurniju pozadinu, ali je u međuvremenu ta sigurnost postala mnogo skuplja negoli je prije bila. K tomu je veza stručnjaka, koji se kao angažirani intelektualac obraćao širim društvenim skupinama, barem djelomično prekinuta. Došlo je do lomova u komunikaciji, a počevši od svijeta medija, angažiranog intelektualca sve češće mijenja model "celebrity-intelektualca”. Taj tip povezuje proces na koji je Bourdieu već ranije upozoravao i koji sociolog Lewis Coser preciznije definira kada govori o "celebrity-intelektualcu", koji među neodređenom i nestručnom publikom traži široku afirmaciju vlastite stručnosti i autoriteta, svjesno zaobilazeći akademsku zajednicu,

barrassing Fox News interview ever' sends Reza Aslan's biography of Jesus to number 1 in the Amazon book charts" (http://www.independent.co.uk/arts-entertainment/tv/news/most-embarrassing-fox-news-interview-ever-sends-rezaaslans-biography-of-jesus-to-number-1-in-the-amazon-book-charts-8737668.html).

4 Pierre Bourdieu, On Television, New York 1999.; vidi također: Pierre Bourdieu, "O televiziji, pozornica i kulise", Europski glasnik, 10/2005., br. 10, 271-308.

5 Amitai Etzioni, "Reflections of a Sometime-Public Intellectual”, PS: Political Science \& Politics, 43/2010., 652. 
odnosno njezine etablirane sustave kontrole, kritike ili valorizacije stručnoga rada. ${ }^{6}$ Instant uspjeh je, odigra li se uloga "celebrity-intelektualca" pravilno, gotovo zagarantiran, jer šira javnost - uz podršku medijskog svijeta - stvara za akademsku zajednicu u dalekosežnom smislu nepremostiv pritisak. Stoga druga slika upravo navedenih primjera svjedoči i o sveukupnu stanju, unutar kojega i mediji i intelektualci funkcioniraju. Govori nam koliko je česta i svakodnevna postala uloga instant "celebrity-intelektualaca", ali i koliko je medijski svijet u tom smislu manje ozbiljno počeo shvaćati njihovo sezanje prema javnosti.

Intelektualac je postao "potrošna roba”, brza žrtva trenda. Osjetili su to američki intelektualci, stručnjaci za Sovjetski Savez, koji su - bilo da su sami predvidjeli ili, pak, previdjeli raspad SSSR-a - u kontekstu 1990-ih i 2000-ih godina postali gotovo beskorisni, "zastarjeli". Samo nekoliko godina ranije oni su bili traženi. Javno mnijenje, političke analize, diplomacija - sve se ravnalo prema njihovim prosudbama. Preživjeli su samo oni koji su situaciju rano prepoznali i ušli u "tranziciju", a "preporodili" (privremeno) oni koji se danas predstavljaju kao specijalisti za problem aktualne ukrajinske krize. Danas se takvi procesi na televiziji događaju još brže. Svaka nova politička, ekonomska, društvena ili kulturna kriza zahtijeva novog stručnjaka, intelektualca koji će voditi riječ. U vatru se guraju mladi i stari, kriterij odabira sve je upitniji. Nije važna čak ni famozna "televizičnost". Stručnjak koji je zbog javnog dobra spreman otvoriti dijalog sa širim krugom nestručnjaka, bez pravog izbora, bira: krenuti u svijet medija, ponekad i ne u potpunosti spreman, ili ostati izoliran unutar struke i užega kruga stručne, studentske ili lokalne publike.

Iako postoje razlike, svijet tiskanih medija također nije uvijek pogodna platforma intelektualnog angažmana: svojim top listama intelektualaca, "Global thinkersa" ili "Intellektuellen-Rankinga" sugeriraju dodatno koga birati, a koga ne, postaju arbitrov arbitar. U međuvremenu se kolumne i feljtoni gase, ponovno se sužava prostor intelektualnog djelovanja. Nema više prostora za pravilno usmjeren i vođen dijalog, za analitičku prosudbu. Intelektualci se rjeđe ili vrlo rijetko spominju u nekom konkretnom kontekstu.

No, nisu samo mediji odgovorni za današnje stanje. Mnogo odgovornosti snose i sami intelektualci. Prolistamo li Rječnik uvriježenih pojmova Gustavea Flauberta, pronalazimo riječ kritičar. Prema Flaubertu, to je osoba koja je uvijek eminentna, koja smatra da sve poznaje, sve zna i da je sve pročitala. Flaubert uz to predlaže da se takva osobu, ako nam se ne sviđa, naziva Aristarhom ili eunuhom. ${ }^{7}$ Iako povijest pojma intelektualac počinje u 20. stoljeću, Flaubertovo satiričko objašnjenje dovodi se u vezu s konceptom intelektualca. Kako je njemački jezičar Dietz Bering ustanovio, riječ intelektualac izvorno je bila pogrdna riječ koja je karakterizirala lijevo orijentiranu Francusku (u dobro poznatoj aferi Dreyfus), dakle kritičare. ${ }^{8} \mathrm{U}$ javnosti su se često percipirali kao neumorni borci, u pozitivnom ili negativnom smislu. Govorilo se o njihovoj ustrajnosti i čestitosti, kao i o njihovoj manjkavoj lojalnosti prema državi, društvu, sustavu ili vlasti. The Devil’s Dictionary, rječnik koji je po svojoj satiričkoj naravi blizak Flaubertovu, početkom 20. stoljeća govori o osobi koja se diči time što ga se "teško zadovolji, zbog toga što ga nitko ni ne pokušava zadovoljiti" - o kritičaru. ${ }^{9}$ Ambivalentan odnos društva prema kritičarima otvorio je u drugoj polovici 20. stoljeća vrata i prema drugačijim putovima. Danas su, međutim, intelektualci češće teore-

\footnotetext{
Lewis Coser, "The Intellectual as Celebrity", Public Intellectuals: An Endangered Species? (ur. Amitai Etzioni i Alyssa Bowditch), Oxford 2006., 227-228.

7 Gustave Flaubert, Bouvard i Pecuchet. Rječnik uvriježenih ideja, Zagreb 2012., 432.

8 Dietz Bering, Die Intellektuellen: Geschichte eines Schimpfwortes, Stuttgart 1982.

9 Ambrose Bierce, The Devil's Dictionary, Cleveland - New York 1911., 58.
} 
tičari, a ne kritičari. U potrazi za jasnije određenom funkcijom u suvremenome svijetu neki su intelektualci odustali od vječne uloge kritičara ili filozofa. Prihvatili su teoriju kao društveno usmjerenu osnovicu koja je prihvatljivija od bilo kakve izražene filozofije, bilo kakvog idealizma - ili kritičkog stanovišta. Ta se promjena jasno očituje na sveučilištima, gdje je tradicionalnu ulogu filozofije danas zauzela šire osmišljena teorija koja, slično nekadašnjoj njemačkoj filozofiji, teži k povezivanju različitih znanosti u dostizanju univerzalnoga, totaliteta. $S$ druge strane, pojam intelektualca dodatno je proširen ili izmijenjen ako imamo na umu da se u današnje vrijeme sve češće intelektualnost i sam intelektualac povezuju s modernim tehnologijama. Pritom se ne misli isključivo na intelektualca-blogera ili internetskog kolumnista. Misli se i na stručnjake koji razvijaju nove programe, koji se razumiju u svijet virtualnih medija, a prosječnom čovjeku otvaraju sasvim nove mogućnosti rada ili dokolice. Užurbano tako u svakidašnji jezik ulaze potpuno novi tehnički pojmovi. Danas govorimo o umjetnoj inteligenciji, a na mozak češće gledamo kao na "računalo". Čovjek se, dakako, ne svodi na norme i varijable, no, bez obzira na to, usporedba ljudskog mozga s računalom danas ostaje ustrajna. A ne radi se samo o nespretnoj analogiji: tehnološki obrat koji se događao u posljednjim desetljećima čovjeka je okrenuo prema egzaktnosti tehničkih i prirodnih znanosti. Brojna otkrića na području računarstva, fizike, biologije, medicine i drugih znanosti usmjerila su veliku pozornost na ljude koji stoje iza tih otkrića: oni su ti kojima se građani okreću, kojima vjeruju i čija istraživanja prate. Takav obrat, pomiješan $s$ ideologiziranim i pojednostavljenim konzumerizmom, potrebom da se neprestano traži neki "proizvod", negativno se odrazio na humanističke znanosti.

Humanističkim znanostima nije pomoglo ni sve raširenije antiintelektualno raspoloženje. Iako se antiintelektualizam može dotaknuti svih oblika znanosti i akademskog života, upravo zbog potražnje za konkretnim, gotovim rezultatima, ponajviše je usmjeren na humanističke znanosti. ${ }^{10}$ Pojednostavljeno rečeno, humanisti nisu potrebni tržištu rada te za njihova znanja i mogućnosti većina nema razumijevanja. Stajalištu je zasigurno doprinijela i ekonomska kriza. I dok se antiintelektualizam u teoriji uglavnom povezivao $s$ totalitarnim sustavima, pojam je, posebice u suvremenome svijetu, rašireniji. Do njega je doveo svakodnevni život obilježen digitalnom tehnologijom i tzv. općim znanjem ili pseudo-intelektualizmom, koje je omogućio upravo suvremeni stil života. ${ }^{11}$ Sjedinjene Države kao jedno od izvorišta takvog "suvremenog stila života" postaju, upravo zbog toga, poprište najjačih debata oko antiintelektualizma - ne znači to, međutim, da je fenomen isključivo američki. ${ }^{12} S$ europske strane tomu fenomenu najbliža je Velika Britanija. Primjećuje se ovdje stoljetna filozofska razdijeljenost kontinenta i anglo-američkog svijeta, okrenutog empiriji. ${ }^{13}$ Od Edmunda Burkea do današnjeg politički desnog, konzervativnog populizma proteže se nit antiintelektualne kritike filozofije, odnosno intelektualaca općenito koji

10 Prirodne znanosti se, $s$ druge strane, često suočavaju s neprihvaćanjem rezultata istraživanja te njihovim ignoriranjem.

11 Susan JАСову, “The Dumbing of America” (http://www.washingtonpost.com/wp-dyn/content/article/2008/02/15/ AR2008021502901.html).

12 Mišljenju zasigurno doprinosi kritika američkoga obrazovnog sustava te razne začuđujuće odluke pojedinih saveznih država, kao na primjer nespominjanje evolucije i geološke starosti Zemlje u školskim udžbenicima u Kanzasu 1999. godine ili zakon koji zabranjuje određene knjige u školskom sustavu u Arizoni iz 2010. godine, što su samo neki primjeri. Uz bilješku 10, vidi i Paul Nevins, “Is Anti-Intellectualism As American As Apple Pie?” (http://open.salon. com/blog/paul_nevins/2011/03/11/is_anti-intellectualism_as_american_as_apple_pie).

13 Ed Rooksвy, "Britishness and anti-intellectualism” (http://www.opendemocracy.net/ourkingdom/ed-rooksby/britishness-and-anti-intellectualism). 
se percipiraju kao slabo učinkoviti, teorijom ograničeni "nepraktičari”. Pritom se, također, radi i o svojevrsnom pokretu, pobuni protiv ustaljenih normi i sustava visokog obrazovanja i svih unutarnjih pravila i simbola koje ono nosi sa sobom. Takvu reakciju omogućio je tehnološki napredak, prvenstveno razvojem računala, pomoću kojih u svakom trenutku zainteresirana strana može vrlo lako doći do potrebnih informacija i podataka; starinsku je enciklopediju, kao projekt prosvjetiteljstva kojime je - da ironija bude veća - dokazivana "korisnost" filozofije, zamijenio internet sa svim svojim mogućnostima, nudeći prividno dostupnije znanje od knjiga kao koncepta intelektualne elite.

Još je Herbert Marcuse upozoravao da tehnološki racionalizam, privlačan zbog toga što djeluje posve objektivno i neovisno, ustvari umanjuje ulogu kritičkog intelektualca. ${ }^{14} \mathrm{Ru}-$ ho objektivnosti i neovisnosti prekriva, međutim, činjenicu da je tehnološki racionalizam povezan s političkim - koji utječe na sve društvene aspekte čovjeka. Na taj način klasični kritički usmjeren intelektualac ostaje često odsječen, odvojen od novouspostavljene veze tehnologije, politike i društva. Prečesto je odgovor intelektualca bijeg u prošlost, samoreferenciranje, pozivanje na stare autore, stare ideje, a da se pritom zanemaruju novi svjetovi, novi problemi. Korpus znanja se, dakako, povećao s obzirom na prošla vremena, pa je svojevrsna historiografija svakoj humanističkoj znanosti nužna. Međutim, tu leži i opasnost od preopterećenosti prošlim strukturama; moderna filozofija danas je djelomično u krizi jer je postala pretjerano okrenuta vlastitoj historiografiji. U tom su procesu često zaboravljeni odgovori na pitanja ljudske budućnosti: filozofija je okupljena prošlim idejama i konceptima, a kada i pokušava na otvoreniji način ući u dijalog s društvom, obično odgovara na pitanje "kamo ili zašto negdje idemo" (epistemološka pitanja zbog kojih je Michel Foucault suvremenu filozofiju povezivao s politikom i povijesnom znanosti, a sebe smatrao povjesničarom $)^{15}$ prije negoli "kako shvatiti novi svijet i kako o njemu misliti". Filozofija prolazi tešku krizu identiteta, boreći se među drugim humanističkim znanostima dokazati da nije zastarjela ili neprilagođena vremenu. Iako nitko ne dovodi u pitanje njezinu korist ili pripadnost modernoj humanistici (koju je u velikoj mjeri i sama definirala, kao što je utjecala i općenito na shvaćanje "modernosti" koje je danas rašireno), sve se češće treba zapitati jesu li teme kojima se filozofi bave relevantne u općedruštvenom smislu, odnosno jesu li znanja i vještine kojima se mladi filozofi uče prilagođena na suvremeni set problema i pitanja? "Kriza" filozofije u mnogočemu navodi na paralele s "krizom" intelektualaca danas: rasprave u javnosti sve su više i više usmjerene na to tko je "pravi filozof", a tko nije. Slično je i kod intelektualaca. Veliki naslov u novinama izmamio je "sukob na filozofskoj ljevici”, no sadržaj sukoba Noama Chomskoga i Slavoja Žižeka gotovo da i nije postojao Chomsky je Žižeka, zajedno s Lacanom i Derridom, opisao kao "intelektualnog pozera", na što je Zižek odgovorio... Kako su hrvatski komentatori rasprave u novinskom članku primijetili, prave poante u toj debati nije bilo. ${ }^{16}$ Primjećuje se teško povezivanje različitih segmenata koje je potrebno zadovoljiti u današnjim akademskim i neakademskim uvjetima. Naime, već je odavno postalo jasno da akademsko tržište u brojnim slučajevima diktira i usmjerava karijeru humanista, što ih uvodi u svijet koji je često odvojen od svijeta konkretnih problema i djela ili etičnosti u općem smislu. Nadalje, teško je postalo definirati odnos

14 Herbert Marcuse, "Some Social Implications of Modern Technology", The Essential Frankfurt School Reader (ur. Andrew Arato i Eike Gebhardt), New York 1982., 138-162.

15 Michel Foucault, Politics, Philosophy, Culture: Interviews and Other Writings, 1977-1984, Routledge $2013 ., 122$.

16 “Žižek protiv Chomskog. Sukob na filozofskoj ljevici” (http://www.jutarnji.hr/sukob-noam-chomsky-i-slavoj-zizek/1115186/). 
intelektualca i politike: jedni od nje bježe, drugi se javljaju kao vatreni zagovornici neke političke orijentacije. Uz to, može li, ali i treba li uopće intelektualac biti i apolitičan? I Platon je u svojoj Republici smatrao idealnim oblik vladavine na čelu s intelektualcima koji bi u sebi spojili teoretsko znanje i njegovu konkretnu primjenu. Ideja vrijedna jednostavnijih vremena i društava. Upravo zato im sustav danas najčešće udjeljuje položaj savjetnika; jer jednom kada se pokazalo da demokracija ne znači nužno politiku odgovornosti, povećala se izloženost u javnom sektoru, a smanjio prostor za idejne i ideološke pristupe, pa su otvorena vrata različitim, već spominjanim antiintelektualizmima, pragmatizmima ili pak pseudointelektualizmima i populizmima.

Iako je danas intelektualcu prividno moguće zahvatiti nepojmljivo velik prostor, barem u odnosu na ranija razdoblja, njegov je prostor djelovanja istovremeno vjerojatno uži nego ikada. Intelektualac više ne vodi polemike u novinama, ne piše redovne kolumne; to čine tek neki. Drugi su se odlučili biti "neovisniji" pa pišu blog ili imaju internetsku stranicu, kao što su philosophysmoker.blogspot.com ili intellectualsdc.com. Treći su aktivni na radijskom programu, kao što je "The Axis of Justice Radio Network". Četvrti nastupaju redovno na televiziji i obraćaju se naciji. Peti pišu knjige koje svi čitaju, šesti pišu knjige koje nitko ne čita. Brojni jednostavno šute, iako prema svojim idejama te ponekad i djelima imaju itekako puno za reći. Anything goes, govorilo se nekada u svijetu glazbe i filma. Sredinom 1950-ih godina sve se češće raspravljalo o modelu angažiranog intelektualca koji je u svijetu potreban, ali i sve uočljiviji. Primjera je zaista mnogo: Adlai Stevenson u politici, J. D. Salinger ili Albert Camus u književnosti, Helmut Gollwitzer u teologiji, Roland Barthes i Ortega y Gasset u filozofiji - da se spomenu tek neki iz naoko beskonačnog niza. No, suprotno tomu, od 1980-ih pa sve do danas proteže se niz više ili manje uvjerljivih naslova knjiga iz pera književnika, sociologa, teoretičara ili povjesničara koji govore o nestanku angažiranog intelektualca, propasti "intelektualnog svijeta" koji je karakterizirao dvije trećine 20. stoljeća. Jean-François Lyotard 1980. godine je u polemici s Maxom Gallom u Le Mondeu govorio o "nadgrobnom spomeniku intelektualca". Već spominjani jezičar Dietz Bering 1982. godine istraživao je intelektualce u prošlosti, tragajući za pojmovnom poviješću "jedne pokude". S druge strane oceana pojavljuje se knjiga The Last Intellectuals: American Culture in the Age of Academe (1987.) povjesničara Russella Jacobyja, koji komparatističkim pristupom uspoređuje nekadašnje odlike američkog društva i njegovu aktualnu situaciju koja je prouzrokovala "nestanak" intelektualca. Unatoč tomu što je od spomenutih debata prošlo više od tri desetljeća, i danas se ipak govori još o rijetkim intelektualcima, onima koji postoje i nisu izumrli.

Takva se negativna percepcija budućnosti intelektualca može prihvatiti samo ako se radi o kakvom povijesnom modelu ili tipu intelektualca za kojega želimo da funkcionalno služi u svrhu društvena dobra, unatoč tomu što se vremena i okolnosti mijenjaju. Je li današnjem društvu potreban Émile Zola? Svakako. Međutim, potrebno je i mnogo više, potrebne su komponente koje u Zolino vrijeme, tijekom afere Dreyfus, nisu bile razvijene, očite ili uopće postojeće. Drugim riječima, ako je važan dio intelektualčeve misije društveno dobro, intelektualci trebaju uvidjeti potrebe i uvjete funkcioniranja društva. Ako se na trenutak vratimo na drugu sliku s početka ove rasprave, ne uočavamo samo promjene u načinu komunikacije, samoprezentacije ili percepcije intelektualaca ili onih koji su nam predstavljeni kao intelektualci. Promijenila se i platforma diskusije: dok je intervju s Rezom Aslanom vrlo brzo postao skandalozno jednostavan i neugodan razgovor, prava diskusija o intelektualnim implikacijama intervjua, položaju akademski etabliranih stručnjaka ili 
Aslanovim djelima vodio se prije i poslije intervjua u virtualnom prostoru internetskih foruma i blogova. Taj je prostor, danas možemo reći, već neko vrijeme okušan u smislu intelektualnog javnog angažmana, što je ukazalo na nekoliko točaka. Internet nudi slobodu, daje prostora tihom ili manje popularnom glasu, otvara nebrojene mogućnosti djelovanja i povezivanja, ali pritom nameće vlastita pravila, vlastitu logiku, s kojom su intelektualci više ili manje upoznati. Iako su forumi i blogovi mjesta na kojima svatko može biti izdavač i autor, Amitai Etzioni upozorava: nije dovoljno samo govoriti, netko vas mora i slušati. Javni su intelektualci toga svjesni, pa ponekad biraju prečac - objavljuju na internetskim forumima tekstove ili knjige koje možda nose snažnu poruku, ali nisu podržani detaljnim istraživanjem. ${ }^{17} \mathrm{~S}$ druge strane, spominjane društvene promjene upravo se jasno očituju i na one koji - slušaju. Jedan recentan tekst Marka Morforda, kolumnista San Francisco Chroniclea, upozorava na nove uzraste djece koja se teže nego ikada suočavaju s koncentriranim čitanjem knjiga, ali im pritom sam koncept staromodne knjige naspram sve prisutnijih tableta i pametnih telefona postaje sve više stran. ${ }^{18}$ Morford govori "iTrained", a to se ne odnosi samo na najmlađe uzraste, već i one starije, koji su putem različitih novih načina čitanja ili komuniciranja nesvjesno prihvatili potpuno nov stil i radikalno drugačiji način nelinearnog razmišljanja, koji se odražava na koncentraciju, formulaciju vlastitih misli, načina analize i evaluacije - dakle na komponente koje se nalaze u sferi intelektualnosti i intelektualne rasprave.

Međutim, u današnjem se svijetu ne umnožavaju samo načini komunikacije intelektualaca i javnosti. Uz davno ustaljene oblike intelektualnog toka, razmjene i dijaloga, kao što je književnost ili klasična glazba, sve su češće prihvaćeni drugi vidovi kulture koji su se nekada strože izdvajali: tko će danas poreći da se velik broj igranih, dokumentarnih ili animiranih filmova bavi intelektualnim temama ili da stihovi raznovrsnih "zabavnih" glazbenika kao što su Thelonious Monk, Brian Eno ili Roger Waters (da se spomenu samo neki) ne sadrže bitne intelektualne poruke?

No, povrh toga svijet znanosti već desetljećima radi na povezivanju računalne inteligencije i ljudske inteligencije, na mogućnostima novih spoznaja povezanih s radom ljudskog mozga i samog koncepta ljudske inteligencije. U povijesti se, naročito od prosvjetiteljstva, koncept sata kao mjerodavnog sustava ovladavanja vremenom često uspoređivao s procesom razmišljanja ili mozgom općenito. Na mjesto sata u drugoj je polovici 20. stoljeća stupalo računalo; umjetnost i popularnu kulturu preplavile su vizije svemoćnih inteligentnih računala koje služe ili su prijetnja čovječanstvu, a postupno se i o ljudskom mozgu počelo govoriti kao o "profinjenom računalnom sustavu" - što, dakako, nije ni približno točno. Analogno vezi uma i mozga, koncept umjetne inteligencije proučavao je vezu pojedinih programa i računalne sklopovske podrške (hardvera). Cilj jake umjetne inteligencije (Strong $A I)$ nije samo analogno proučavanje uma, već i razvoj programiranja računala koja su sposobna misliti i razmišljati. Međutim, računala od početnih razvojnih stadija do danas rade prema istom ili sličnom principu; problemi s kojima se suočavaju svode se, u pojednostavljenom objašnjenju, na matematičke kodove. Zbog toga se paralelno s konceptom umjetne inteligencije razvijaju i vode projekti kao što je "Human Brain Project" koji se provodi u Švicarskoj pod vodstvom École polytechnique fédérale de Lausanne, ali u suradnji s brojnim drugim znanstvenim institucijama. Taj interdisciplinarni projekt nadovezuje se na brojna

\footnotetext{
7 A. Etzioni, "Reflections of a Sometime-Public Intellectual", 652.

18 Mark Morford, "The tragic death of the good read" (http://blog.sfgate.com/morford/2014/04/08/the-tragic-deathof-the-good-read/).
} 
neurološka otkrića prethodnih dvadeset godina, pomoću kojih je prikupljeno više informacija o funkcioniranju i radu mozga. Projekt u svojoj srži želi simulacijom oponašati rad mozga u cijelosti te na taj način obrazložiti pitanja kojima se znanstvenici bave već desetljećima. Nova istraživanja mozga u budućnosti će uz pomoć spomenutog i sličnih projekata davati znanstvene odgovore o procesu razmišljanja i funkcioniranju uma, koje će trebati povezati s filozofsko-sociološkom interpretacijom intelektualnog procesa. Stoga nije zanemariva mogućnost redefiniranja opće definicije intelektualaca, koja je, kako se i iz ove rasprave vidi, već ionako u društvenom smislu ovisna o raznim modelima.

Vratimo se još jednom na početak ove rasprave. Prenesemo li situaciju iz druge slike na općenito stanje društva, moguće je da se lom u komunikaciji ponovi. Dapače, radi se samo o jednome primjeru loma koji je sve češći i sve uočljiviji: intelektualac koji se pred agresivnošću povlači u sigurnu zonu titula i akademskih postignuća, dok je pritom bit intelektualnog djelovanja relativizirana ili neshvaćena. $S$ druge strane, moguće je predvidjeti da se proces kojim je stvoren "celebrity-intelektualac" na tom obliku i ne zaustavlja, izazivajući daljnje poteškoće u komunikaciji, promičući amorfne i heterogene društvene skupine kao meritorne faktore ne samo stručnih već i etičkih kategorija. Intelektualac se u tom smislu doista pronalazi na marginama, tendira biti "amater" u smislu koji je Edward Said predložio. Postavlja se, između ostalih, pitanje: shvaća li društvo danas doista tko i što su intelektualci? Shvaćaju li sami intelektualci svoju ulogu i odgovornosti? Odgovori zasigurno nisu jednoznačni. Pitanje odgovornosti intelektualaca u današnjem je vremenu, pak, sve važnije. Brojni intelektualci upozoravaju da su razvoj akademske zajednice, dakle promjene u visokome obrazovnom sustavu, uloge sveučilišnih profesora, ali i tradicionalna sigurnost koju takvi poslovi daju u smislu stalnog zaposlenja utjecali na to da intelektualci-specijalisti za određena područja bez mnogo odgovornosti komentiraju aktualna društvena pitanja, a da pritom nisu u potpunosti informirani, ili problem kojim se bave ne leži ni u širem opisu njihova područja.

Američki sudac i intelektualac Richard A. Posner u jednom je svojem tekstu napomenuo da postoji "obrazac neobazrivog ponašanja" akademskih intelektualaca koji se obraćaju javnosti, navodeći brojne krive procjene ili neodgovorne izjave koje su neki stručnjaci unatrag nekoliko desetljeća davali - bez ikakvih bitnih posljedica. ${ }^{19} \mathrm{~S}$ druge strane, unutar suvremenih kategorija znanja i ideja skoro nezamisliv kozmos antičke grčke moći promišljanja danas je nedostižan, barem na razini snage spoznaje ili intuitivnosti. No, nedostižan postaje i taylorovski svijet intelektualca koji se putem televizije okreće širokoj javnosti i s njome iz tjedna u tjedan razvija određenu razinu komunikacije, koja se nalazi u njegovoj sferi, ali je relevantna širim krugovima. Sama činjenica da su ta vremena, koliko god udaljena ili bliska bila, prošla, a da je intelektualac i dalje pojam koji opstaje u društvu, govori nam o jednoj od najvǎnijih sposobnosti intelektualca danas: o njegovoj prilagodbi. Dok god snaga razuma i razumijevanja prima i prilagođava društvena kretanja, prostor za nove ideje ostaje postojan. Riječima Friedricha von Hayeka, intelektualac uvijek traga za onime što mu je "shvatljivo" (intelligible) u društvu, preferira nešto što je vidno usmjereno prema dobrobiti. Intelektualčeva kreativnost u tom je smislu istovjetna umjetnikovoj: intelektualac stvara u skladu s vremenom, ponekad usprkos, ponekad uz pomoć njega. Međutim, on i dalje stvara. Ako postoji potreba da se dodatno definira "posao" suvremenog intelektualca, dakle konkretna upotreba ideja ili onoga što stvara, dopušteno nam je uspostaviti analogiju sa zanatom povijesnog istraživanja, historijskom znanosti. Iako povjesničari nisu

19 Richard A. Posner, "In Over Their Heads", Boston Globe, 27. 1. 2002., C1. 
uvijek skloni izvanstručnim istupanjima, barem ne u ulozi angažiranoga javnog intelektualca, zadatak povjesničara, njegov postupak stremljenja k objektivnoj i racionalnoj organizaciji ljudske prošlosti, objašnjenju, humaniziranju, dubinskom shvaćanju, razlaganju i razlikovanju društva ili društvenih kretanja u prošlosti, blizak je postupku koji intelektualac primjenjuje na sadašnjost ili budućnost $-s$ jednakom mjerom opreza i odgovornosti, iako aparati kritike i provjere nisu jednaki, što osobni ulog čini manjim, ali kolektivni većim. U tom se smislu ova kraća rasprava razvija analognom upotrebom metode koja je poznata u historiografiji, ali i drugim društvenim znanostima, primjerice etnologiji: radi se o usmenom propitivanju koje se provodi u formi razgovora (intervjua), sastavljenim uz definirane metodološke i koncepcijske odrednice. Metode različitih društvenih znanosti u ovome slučaju pružaju relevantne odgovore o stanju intelektualaca u svijetu, različitim percepcijama položaja i okvira unutar kojega oni djeluju, ali i historijski bitan pogled unatrag. Model takva povezivanja pronalazimo u razgovorima koje je prije pola stoljeća vodio povjesničar Ved Parkash Mehta s britanskim intelektualcima ili knjizi razgovora novinara T. R. Fyvela koja sadrži razgovore s britanskim, francuskim i njemačkim intelektualcima, Intellectuals Today: Problems in a Changing Society. ${ }^{20}$ Drugim riječima, u ovome je slučaju razgovor omeđen, preciznije usmjeren (kontrolnim) modelima koji omogućavaju otvaranje nove razine dijaloga, izravno nadovezanog na "forumski" ili "simpozijski" oblik, koji je u većoj mjeri odredio i Desničine susrete 2013. godine. Tako je i ova rasprava zamišljena kao prilog otvaranju višeznačnog i višesložnog dijaloga o položaju, ulozi, modelima i mogućnostima intelektualca u današnjem vremenu. Ona je, dakle, suštinski bliska samo definiciji intencija Desničinih susreta kao takvih.

\section{The Intellectual In Front of a Mirror: A Discussion of Contemporary Intellectuals}

The Croatian Encyclopaedic Dictionary from 2003 defines an intellectual as "a thinker whose public work is a force for morality and humaneness within a society". That understanding of the public role of the intellectual is a construct dating to the turn of the turn of the 20th century. The issue of the intellectual's position and role in the ever-changing contemporary society, as well ass the expectations the society sets before the intellectuals have always been relevant. During the entire 20th and 21st centuries, philosophers, writers, historians, sociologists and other theorists have discussed the term, thus contributing to this "monument to a problem" (Denkmäler von Problemen), as Reinhart Koselleck put it. The political scandal known today as the Dreyfuss affair and Émile Zola's open letter marked the beginning of a trend that has since snowballed. The emergence of mass media has begotten an industry of culture and science, while, linking it to prosperous universities, defining the intellectuals' position in society in decreasingly uncertain terms. The term of the "intellectual" gradually entered literary and scholarly discourse, taking on different meanings in different circumstances. In the mid-1950s, American critics and theorists introduced the model of an activist intellectual. In contrast, from the 1980s onwards, a number of more or less convincing books, written by diverse writers, sociologists, theorists and historians,

20 V. P. Мenta, The Fly and the Fly-Bottle: Encounters with British Intellectuals, London 1961.; Tosco R. Fyvel, Intellectuals Today: Problems in a Changing Society, New York 1968. 
which address the disappearance of "a socially active intellectual", the downfall of "the world of the intellectual" which marked two thirds of the 20th century. In 1980, Jean-François Lyotard, polemicizing with Max Gall, referred to "the intellectual's tombstone" in Le Monde. German linguist Dietz Bering conducted a research of past intellectuals in 1982, examining the "history of a curse" (Die Intellektuellen: Geschichte eines Schimpfwortes). Simultaneously, across the ocean, the historian Russell Jacoby published a book entitled The Last Intellectuals: American Culture in the Age of Academe (1987), wherein he uses a comparative approach to juxtapose the former characteristics of the American society and the current situation, ostensibly caused by the "disappearance" of the intellectual. Despite there having passed more than three decades since those debates, even today there are mentions those rare intellectuals, who are still active and aren't extinct. The breadth of education available, technological advancements and new mass media created one of the many contradictions of the new era: man does not think about society, despite participating in current events. Technology breeds a kind of mindlessness, mindless action, because it is self-applicable. Eric Hobsbawm was right when he claimed that modern technology educates younger generations, lending itself to quick use, without much thought, but the existence of science and the desire for its further advancements remain a guarantee of the intellectual's position in modern society. It is particularly interesting to see whether the division between intellectuals in the public eye and those in academia is still valid today, or if new means and "rules" of communication force the intellectual to be exceedingly versatile in order to be heard. At the same time, the question arises whether intellectuals are even capable of responding to current problems. Can an intellectual be universal and is universality something to be strived to? On the other hand, does it make sense to strive for specialization among intellectuals or have we reached a point where we should redefine the term? There are, of course, other problems: from those bordering on the political, those which are indeed purely political, all the way to those concerning cultural heritage. Additionally, tradition of intellectual life and debates, as well as dominant influences must not be ignored. The oral history research method, surveys, a sort of oral history, opens new views of the past and the present of a circle, its attitude towards the way society develops and the world we live in through broader contacts with Croatian and international intellectuals. This provides the possibility of exploring the current situation, but also of analyzing the results of a longue durée process stretching through the second half of the 20 th and the first half of the 21 st century.

Keywords: the intellectual, the media, change, computer, society, conversation

\section{$\cos$}

\section{Literatura}

Reza Aslan, Zelot: Život i vrijeme Isusa iz Nazareta, Zagreb 2013.

Matilda Battersby, “'Most embarrassing Fox News interview ever' sends Reza Aslan's biography of Jesus to number 1 in the Amazon book charts" (http:/www.independent.co.uk/arts-entertainment/tv/news/most-embarrassing-fox-news-interview-ever-sends-reza-aslans-biography-ofjesus-to-number-1-in-the-amazon-book-charts-8737668.html).

Dietz Bering, Die Intellektuellen: Geschichte eines Schimpfwortes, Stuttgart 1982.

Ambrose Bierce, The Devil's Dictionary, Cleveland - New York 1911.

Pierre Bourdieu, On Television, New York 1999.

Pierre Bourdieu, "O televiziji, pozornica i kulise”, Europski glasnik, 10/2005., br.10, 271-308.

Lewis Coser, "The Intellectual as Celebrity”, Public Intellectuals: An Endangered Species? (ur. Amitai Etzioni i Alyssa Bowditch), Oxford 2006., 227-228.

Amitai Etzioni, "Reflections of a Sometime-Public Intellectual”, PS: Political Science \& Politics, 43/2010., br 43, 651-655. 
Gustave Flaubert, Bouvard i Pecuchet. Rječnik uvriježenih ideja. Zagreb 2012., 432.

Michel Foucault, Politics, Philosophy, Culture: Interviews and Other Writings, 1977-1984, Routledge 2013.

Tosco R. Fyvel, Intellectuals Today: Problems in a Changing Society, New York 1968.

Susan Jасову, “The Dumbing of America” (http:/www.washingtonpost.com/wp-dyn/content/ article/2008/02/15/AR2008021502901.html).

Herbert Marcuse, "Some Social Implications of Modern Technology", The Essential Frankfurt School Reader (ur. Andrew Arato i Eike Gebhardt), New York 1982., 138-162.

Ved Parkash Menta, The Fly and the Fly-Bottle: Encounters with British Intellectuals, London 1961.

Mark Morford, “The tragic death of the good read" (http://blog.sfgate.com/morford/2014/04/08/ the-tragic-death-of-the-good-read/).

Paul Nevins, "Is Anti-Intellectualism As American As Apple Pie?” （http://open.salon.com/ blog/paul_nevins/2011/03/11/is_antiintellectualism_as_american_as_apple_pie).

Ed Rooksby, "Britishness and anti-intellectualism” (http:/www.opendemocracy.net/ourkingdom/ ed-rooksby/britishness-and-anti-intellectualism).

Richard A. Posner, "In Over Their Heads”, Boston Globe, 27. 1. 2002., C1.

Mary Elizabeth Williams, “The Reza Aslan interview reveals our collective ignorance” (http:// www.salon.com $/ 2013 / 07 / 30 /$ the_reza_aslan_interview_reveals_our_collective_ignorance/).

“Žižek protiv Chomskog. Sukob na filozofskoj ljevici” (http://www.jutarnji.hr/sukob-noam-chomsky-i-slavoj-zizek/1115186/).

\section{Prilog: Razgovori na temu "Intelektualac danas"} (razgovore vodili Filip Šimetin Šegvić i Nikolina Šimetin Šegvić)

\section{Što za Vas osobno znači biti intelektualac u današnjem vremenu? Mogu li se pojam i uloga modernog intelektualca definirati?}

Carol Becker: Ima mnogo ljudi koji o specifičnim temama znaju jako puno. To su stručnjaci. No, to ne znači nužno da su u stanju o tim temama misliti na apstraktan način. Po mom mišljenju, intelektualac je onaj koji dubinski razmišlja o određenom problemu, situaciji ili stanju i koji je sposoban to izdvojiti i analizirati. Također bih dodala, intelektualac je u stanju kontekstualizirati to što se analizira, i to u odnosu na povijest, društvo i strukture znanja.

Gerhard Ruiss: Više mi se sviđa pojam “današnji”. “Moderni” ljudi su oni ljudi koji se bave modama. Nepovjerljivost i distanca prema potrošačkom društvu i ekonomije upravljanja informacijama potrebniji su nam nego ikada. Danas biti intelektualac znači točno procjenjivati u kojoj se mjeri, primjerice, određenim mogućnostima u javnosti staviti na raspolaganje i kada te mogućnosti počinju raspolagati vama. Filozof, koji može objasniti posebnu vrijednost i posebno značenje i posebnu povezanost svega i svačega, sasvim se sigurno rado vidi posvuda, čak i kao ukras, odnosno kao predstavljač u dugim promidžbenim porukama. On nudi robu, koju treba hvaliti ili upozoriti na njezinu važnost, a 
koju ne posjedujete. Primjerice: "Mi imamo najbolji XYZ, koji služi i višoj svrsi." No, taj pristup jednostavno ne donosi ništa.

Nathan Glazer: Po meni, intelektualac je onaj koji je uključen u vodeće ideje svojega vremena, utječući na umjetnost, politiku, društveni život, onaj koji komentira i povremeno zauzima određena stajališta unutar kontroverza. Autoritet dobiva na temelju rada u sferi koja se bavi idejama, pa makar one i nisu izravno povezane s pitanjima oko kojih intelektualac zauzima svoj stav. Termin se prvi put pojavio, čini mi se, u sklopu slučaja Dreyfus oko kojega su postojali različiti stavovi, a model za taj termin pružao je Zola.

Boris Vezjak: [Biti intelektualac u današnjem vremenu] ne znači baš puno; opća uloga intelektualaca sigurno se smanjila. Volim biti jako konkretan: živim u Mariboru gdje sam 2011. godine napisao javno pismo s oko 30 potpisnika, u kojemu sam tražio ostavku našeg župana zbog koruptivnih djela. Mediji su ovo okarakterizirali kao "pismo mariborskih intelektualaca”. Kasnije sam iz radoznalosti obavio jednostavnu medijsku analizu i ustanovio da termin "mariborski intelektualac" gotovo 10 godina nije bilo upotrijebljen u lokalnom časopisu Večer, koji je jedini dnevnik u tom djelu Slovenije. Možda i šire. Vidite onda jasno, što to znači biti intelektualac?

Moja koncizna definicija bila bi otprilike sljedeća: intelektualac je osoba koja samoinicijativnim javnim angažmanom pomoću stručnih znanja pridonosi općem dobru nekog društva i iskazuje pripadnost njegovu napretku. Ne vjerujem da je javni intelektualac u punom smislu taj koji u takvu pristupu nije samoinicijativan (znači da nešto uradi samo kada se to od njega traži) ili taj koji je angažiran samo iz perspektive uskog područja svojega rada. U neku ruku taj "širi" opis često postaje zloupotrijebljen. Još jedan primjer: na našem sveučilištu dekani vole sve studente nazivati "budućim" intelektualcima. Naravno, to će postati samo neki od njih.

Carlo Bernardini: Intelektualac danas, kao i u prošlosti, osoba je koja je kulturološki angažirana/umiješana u društvenu i političku svijest svijeta koji je okružuje, s ciljem prenošenja veće svijesti u zajednici o tome što se treba mijenjati i razvijati.

Simon Sheikh: Moja definicija intelektualca slijedi Gramscijevo shvaćanje "organskog intelektualca", što podrazumijeva nekoga tko je angažiran u društvenoj i klasnoj borbi i stvaranju. Dok je buržujski intelektualac navodno bio iznad i izvan društvenih previranja i govorio je s položaja predodređene razumnosti, organski je intelektualac nešto poput osobe koja smišlja reklame kapitalističke razmjene ili osobe koja organizira rad. Slijedimo li tu nit do u postmoderno vrijeme, radi se možda o voditelju talk-showa ili zvijezdi televizijskog realityja. Oni tu ulogu preuzimaju bez imalo potrebe za nepristranim, superiornim intelektualcima nekadašnjeg vremena. No to, dakako, govorim samo iz hegemonijske perspektive potrošačkog kapitalizma, a ne iz perspektive nesigurnog radnika ili onih koji su izvan svega - subalterni. Postavlja se tu političko pitanje - tko i kako ih predstavlja? Ako, drugim riječima, subalterni ne mogu govoriti, može li netko govoriti u njihovo ime?

A za nekoga tko je akademski građanin, to je vrlo bitno pitanje. Kako definirati klasni položaj i politički afinitet akademskih građana? Komu se obraćamo? U ovom nam je slučaju jako važan Foucaultov rad, jer on nije vidio intelektualca kao univerzalista, već kao pojedinca koji je uključen u specifične borbe, kojega interesiraju i teorijski rad 
i aktivistički angažman, na način da jedno utječe na drugo (kako je pokazao u svojim radovima o sustavu kažnjavanja).

Chester Finn Jr.: Jedan dio problema koji predstavljaju moderna vremena, barem kada je riječ o naprednim društvima i gospodarstvima koja se oslanjaju na edukaciju, jest da mi i dalje inzistiramo na staroj podjeli između intelektualaca i "svih ostalih". To je bilo razumljivo u vrijeme kada je relativno mali dio ukupne populacije bio educiran i čitao mnogo knjige (i mnogo manje ih pisao), no danas većina ljudi od vas zahtijeva da imate prilično dobro znanje, da možete logički razmišljati te da posjedujete analitičku moć (i tendencije) "intelektualaca". Uglavnom je to za "primijenjene" svrhe, dakle ne samo u smislu akademske karijere. No, bilo bi mi drago kada bi spomenuta razlika postala manje jasna.

Henry A. Giroux: Intelektualci su ljudi koji cijene ideje, misle na drugačiji način kako bi djelovali na drugačiji način te koriste dostupna sredstva kako bi se bavili važnim društvenim pitanjima sa, kako bi se moglo reći, zastrašujućim osjećajem za društvenu odgovornost i građanskom kuražom. Intelektualci koji su više od samo tehničara misle kritički o određenim idejama i pristupaju im kao temeljnim elementima i individualne misli i društvenih kretanja. Intelektualci trebaju pružati model prema kojemu se stručno povezuje s javnim životom, otvaraju važne društvene i političke teme, govore pred različitim publikama, pomažu građanima na putu prema istinitijem i izraženije kritičkom shvaćanju vlastitih pogleda i njihova odnosa prema drugima i širemu društvu. No, oni trebaju raditi više od jednostavnog postavljanja pitanja. Oni trebaju otvarati javne sfere i formativne kulture unutar kojih dijalog, promišljenost i kritička razmjena nešto znače i unutar kojih se šire. Zygmunt Bauman je u pravu kada kaže da je odgovornost intelektualca da preuzme odgovornost za našu odgovornost - za nas, druge, za širi svijet. Dio te odgovornosti podrazumijeva postajanje moralnim svjedokom, proširivanje političke imaginacije, rad u skladu s društvenim pokretima kako bi društvena i ekonomska pravda uznapredovale, podupiranje pravednosti i davanje značaja obećanjima radikalne demokracije.

Pierpaolo Antonello: U proteklim se desetljećima intelektualac pokušao definirati na različite načine. Svugdje se naglašava javna uloga intelektualca kao 1) parhezijasta, ako usvojimo Foucaultovu terminologiju, koji govori u ime "istine" (jasan primjer daje Roberto Saviano u Italiji); 2) parakletosa, prema definiciji koju posuđujemo od Girarda i koju pronalazimo u srži razmišljanja Edwarda Saida o javnom intelektualcu-osvetniku žrtava, manjina, subalternih kultura ili pojedinih krajeva; 3) agenta provocateura, dakle stalnog kritičara ideologije i kulturne i političke falsifikacije (između ostalih Chomsky, Žižek); 4) medijske starlete, dakle predvodnika, popularizatora, onoga koji javnost koristi u svrhu medijske izloženosti i samopromocije, bez obzira na to kakav se sadržaj pritom pruža ciljanoj publici.

Steve Fuller: Intelektualac je osoba koja živi od proizvodnje i distribucije ideja. Fokus na "ideje" dosta je važan jer znači da intelektualac mora biti prilagođen na komunikaciju s različitim medijima - a ne, primjerice, samo akademskim tekstovima - pomoću kojih se ideje prenose. Intelektualci su u modernom vremenu učinkoviti kroz dvije uloge. Prvo, oni razvijaju imunitet društva samim time što u pitanje dovode stvari koje se uzimaju zdravo za gotovo, i to na način da društvo, i unatoč tomu što možda ne uspijeva u cijelosti prihvatiti provokaciju intelektualca, dobiva jači osjećaj prema vlastitu identitetu i 
veću otvorenost prema širemu svijetu. Drugo, oni djeluju slično onomu što ja nazivam "posrednici distributivne pravde", dakle na način da često pojačavaju glas manjina ili neusuglašenih, koji u protivnom slučaju ne bi dobili ravnopravan prostor za saslušanjem u društvu.

Dietz Bering: Intelektualac sa svojom intervencijom kreće od pojma ljudskog dostojanstva. Tijekom svih njegovih akcija, koje teže uspostaviti neku solidarnost, on je sudionik, ali ne i pripadnik nečega. On uzima kritičku distancu. Iako se razvija unutar čvrste točke "ljudskog dostojanstva", njegov pogled ostaje univerzalan, jer on istovremenim mislima povezuje različite fenomene, jer se trudi biti prisutan i jer se pomoću svoje antisektoralne pozicije nalazi izvan svake osude. Temeljni kritički stav drži postojanim naspram koncepta "ljudskog dostojanstva" kroz jednu jedinu točku, jer je svjestan da se takva baza postiže samo povjerenjem, jer ljudsko dostojanstvo ne postoji kao bilo kakva čvrsta kategorija kroz čitavu vječnost, već se radi o kulturnoj težnji, o ljudskom projektu suprotstavljenom brutalnoj realnosti. Taj odraz, koji intelektualca čitavo vrijeme slijedi, štiti ga od propadanja na razinu ideologa. Jednom rečenicom: moderni je intelektualac angažirani citoyen. Iz toga slijedi: postoji čitava skala sjajnih, potpuno nepobitnih intelektualaca (Zola, Havel, Böll itd.) koja silazi sve do svakodnevnog čovjeka, koji stajališta odozgo zastupa tek kao slabije verzije.

Hauke Brunkhorst: Intelektualci su najjednostavnije rečeno stručnjaci, bilo da se radi o atomskim fizičarima, romanopiscima, pedagozima, filozofima, pravnicima, slikarima ili o nečemu drugome, koji se okreću javnosti i medijima kako bi u političkim temama zauzimali pro ili contra stajališta. Pritom se tijekom diskusije o općim stvarima, kao i svi drugi građani, okreću onomu u čemu su učeni stručnjaci. Intelektualci nisu, međutim, stručni znanstvenici ili estetičari koji sa znanstvenom ili estetskom težnjom za istinom svoje stručno mišljenje otvoreno u javnosti stavljaju na vagu.

\section{Kako ocjenjujete Vašu vlastitu ulogu u društvu? Smatrate li sebe intelektualcem?}

Carol Becker: Smatram se spisateljicom, ali i intelektualkom. Mislim da je moja uloga biti onaj koji objašnjava. Nastojim pisati o pitanjima, idejama i umjetnosti koje bi i drugi, prema mojemu mišljenju, trebali smatrati značajnima. A nastojim to raditi na jako pristupačan način, tako da nitko ne bude isključen iz razgovora - ako u njemu želi sudjelovati. Mislim da je važno umjetnost i ideje u društvenom smislu kontekstualizirati, što također smatram svojom ulogom. Budući da sam i dekan umjetničke škole, sve se te uloge povezuju u želji da umjetnosti budu važne za društvo na različite načine i na različitim mjestima.

Boris Vezjak: Ima neka zamka oko takve presude: gotovo je nemoguće ocijeniti samoga sebe, jer intelektualac ne postaješ pukom deklarativnošću. Zapravo, uvijek te drugi proglase ili učine time. Situacija je slična ako želimo sebe opisati kao moralnu ili vrlu osobu. Nikad ne možemo reći: "Ja sam pravedan", a da to ne zvuči opsceno. Osobno bih želio biti intelektualac i uvijek sam radio u tom pravcu. Ali neka drugi kažu.

Chester Finn Jr.: Smatram se promišljenim kritičarom, provokatorom, osobom koja je komentator i politički savjetnik, koja je uključena u "pravi svijet" obrazovanja, uglavnom kroz primarnu i sekundarnu razinu. Dosta sam načitan i općenito tražim dokaze 
ili nastojim analizirati nešto. Prema tome, vjerojatno jesam i intelektualac, iako to nije moj vlastiti koncept.

Henry A. Giroux: Educirati studente i otvoriti im put prema jeziku koji će proširiti njihov smisao za individualnu i društvenu djelatnost, proširiti njihove intelektualne perspektive, razvijati njihovu sposobnost kritičkog mišljenja i odnos prema širokim publikama. Dio je moje uloge i suradnja s drugim intelektualcima i društvenim skupinama u želji da se bavimo najrazličitijim važnim društvenim temama, političkim pitanjima i ekonomskim temama koje trenutno uništavaju ostatke javnog dobra i demokracije. Posebno mi je važno dokazati da je edukacija središnje svojstvo politike, upozoravajući na to da su intelektualci potrebni u želji da se razviju formativne kulture unutar kojih postoje intelektualni, društveni, kulturni i gospodarski uvjeti, kroz koje se stvaraju angažirani, društveno odgovorni i kritički djelatnici. Svi intelektualci trebaju odbiti da ih se reducira na ulogu, kako je Gramsci nekoć rekao, "stručnjaka u legitimaciji".

Steve Fuller: Da, vidim sebe kao intelektualca, iako za to nisam plaćen. Biti intelektualac nije dio poslovnog opisa osobe koja je akademski građanin (dakako, neki su veliki intelektualci bili i humanisti). Humanisti se tipično, a to možda postaje i sve češća pojava, navikavaju i potiču da ideje prenose sredstvom ograničenog dosega, i to na način da samo to sredstvo postaje poruka. Primjerice, humanisti su skloni vjerovati da se ideje ne mogu na pravi način razviti unutar radijskog programa ili novinske kolumne. Takav stav odmah humanistu priskrbljuje autoritet stručnjaka (s obzirom na to da objavljivanje akademskog članka nije trivijalna vještina), a implicitno intelektualca postavlja kao antiakademsku figuru, jer intelektualac misli da se bilo koji složeni koncept može učinkovito prenijeti i na razinu popularnih medija. Ponekad se tako intelektualac predstavlja u ulozi osobe koja degradira akademsku razinu znanja. Time se, međutim, podcjenjuje prijetnja koju intelektualac predstavlja akademskoj razini znanja, a to je da iz nje izuzima vještine te je na taj način čini suvišnom. Stoga se postavlja pitanje: ako je moguće razumjeti teoriju evolucije koju Richard Dawkins objašnjava u kolumni od 750 riječi, čemu čitati Darwinove goleme sveske, a naročito rječite akademske komentare koji su slijedili Darwina?

Dietz Bering: Smatram se intelektualcem, iako se time ne hvalim. Treba biti tihi intelektualac, na taj način istupati, i to samo u olovnim vremenima. Jer, intelektualac je samo pričuvna vojska demokracije.

Pierpaolo Antonello: U gramscijevskom smislu ja doista i jesam intelektualac; imam specifičnu ulogu u društvu u kojem živim. Predajem u sklopu javne institucije i imam odgovornost da doprinosim oblikovanju intelektualnog profila brojnih studenata na različitim razinama. Moja je uloga i cilj opremiti ih kritičkim i racionalnim alatima, usmjeravati ih i s povijesnog i s hermeneutičkog stajališta kroz kulturnu kompleksnost, povisiti im razinu kritičke samostalnosti i odgovornosti u odnosu na estetske i političke sudove. Iako imam određen odnos s javnim medijima i izdavačima, koji su ključni u procesu širenja mojih ideja, više mi je važan dnevni odnos s mojim studentima, što ima znatno dugotrajniji učinak nego bilo koji oblik javne "indoktrinacije".

Smatrate li da je nužnost današnjih intelektualaca davati, izmedu ostaloga, i političku poruku ili mislite da to nije potrebno? 
Chester Finn Jr:: Naravno da se mnogo suvremenih intelektualaca bavi nepolitičkim (ili samo indirektno političkim) pitanjima, kao što je proučavanje genetičke strukture raznih oblika raka, uzrok postojanja "kanala" na Marsu ili kako povećati žetvu kukuruza. Drugi, pak, pišu pjesme ili predstave. Ali da, bitan dio suvremenih intelektualaca ulazi u problematiku "javne politike", pa stoga imaju i političke stavove i poruke. No, svijet bi bio kudikamo bolji kada bi intelektualci stali na onome što doista znaju, umjesto da osjećaju potrebu za dnevnim javljanjem u vezi sa svakim mogućim javnim problemom.

Boris Vezjak: Dihotomija politično vs. nepolitično lažna je dilema. Vjerujem da su sve poruke intelektualaca nužno nešto što ima političke posljedice, ili nisu poruke intelektualaca. Po definiciji intelektualac je kritički promatrač društvenih zbivanja i njihov komentator. A što je drugo politika nego traženje rješenja za to.

Carlo Bernardini: Obveza intelektualaca u poboljšanju mira u svijetu jest i ostat će uvijek aktualna, ako ne i glavni cilj. Zatim slijedi društveni i politički angažman, kako bi zajednica spoznala što su parazitske strukture koje u svakom društvu koče gospodarstvo i njegov razvoj na način da ga naposljetku eliminiraju.

Uposlijeratnim je godinama diljem Europe i Amerike idealan tip intelektualca bio pisacpreferirajući kao primarne načine izražavanja književne eseje i polemike. Mislite li da je danas došlo do bitnih promjena u tom pogledu? Je li prema Vama, primjerice, film upravo u posljednjim desetljećima potvrdio svoju sve važniju ulogu?

Gerhard Ruiss: Poslijeratni intelektualci raširili su diskusiju i dominirali su njome. Dok je politika izigrala svoju vjerodostojnost, književnici su je očuvali. Čak se i pobjedničkoj politici Saveznika nije u potpunosti vjerovalo. Taj tip poslijeratnog intelektualca sam je sebe nadživio, jer je razrada nacionalizma, fašizma, nacizma, povijesnog rasizma i poslijeratnog uređenja uglavnom već zaključena. Razjasniti nužno, dakako, nije zaključeno, ali to ionako nije zadatak intelektualaca, već politike. Osim ako ga je potrebno demaskirati. No, više ne postoji socijalistički europski istok, iz Europe su nestale vojne diktature, a autoritarne europske države svode se u međuvremenu na rijetke zaostale iznimke. Očito je da se model poslijeratnog intelektualca nadživio i po tome što prozivi i slično iz redova starog sloja intelektualaca nisu usmjereni na Europu, već prema Bliskom i Dalekom istoku ili na Afriku. U sadašnjosti su nam potrebna potpuno drugačija istupanja, kojih dosad još nema. Ako su protestni pokreti uopće i prisutni, relativno brzo se raspadaju unutar sebe samih. Utočište su im potom političke stranke, koje ih vode u smrt. Intelektualac sadašnjosti pojavljuje se kao komentator, čija se reputacija dobro koristi u svrhu legitimiranja uglavnom izuzetno upitnih želja.

Carol Becker: Čini mi se da je i danas pisanje vrlo važno i vrlo dostupno. Ljudi čitaju i pišu blogove, internetske stranice, sve to kroz jezik i slike, iako jezik kao takav nije nestao. Pisanje nije nestalo. Ljudi i dalje najčešće svoje mišljenje izražavaju u pisanom obliku, $s$ obzirom na to da većini ljudi film nije dostupno sredstvo. To je uglavnom još uvijek skupa, kompleksna, kolektivna operacija. Dakako, stvaranje filmova i dalje je jako važno. $\mathrm{Na}$ određene načine to je lingua franca suvremenih kultura, jer ljudi imaju mogućnost svoju priču ispričati unutar svih dimenzija - krajolika, glazbe, slika i jezika. No, to je tek jedna forma. Film, naravno, ovisi u svojoj biti i o pisanju. Ali ima mnogo razina. Učinak dokumentaraca ili narativnih filmova koji se može ostvariti u odnosu na društvena 
pitanja isti je kao i učinak knjiga o društvenim pitanjima. Taj učinak može biti golem. No, sve spomenute forme koegzistiraju. Treba samo pogledati na važnost glazbe za kulturu, koliko je ona utjecajna, na dobre i loše strane. Sve su te forme jedinstvene, ali je, ipak, njihov kolektivni utjecaj dubok. Nije toliko važno raspravljati o izdvojenoj formi, koliko o tome kako je upotrijebiti. Više ne postoje jednostavne hijerarhije.

Dietz Bering: U načelu model "intelektualca” ne ovisi o zanimanju. No, postoje zanimanja koja su u strukturalnom smislu bliska intelektualcima, primjerice pisci. Skoro slobodni od institucionalnih okova, mogu i moraju se, gdjegod je to moguće, sučeliti s realnošću. U tom je smislu za njihovo zanimanje tipičan i "univerzalni pogled" - što kod njih stvara intelektualnu predestiniranost. A uz to su i jaki u riječima.

Hauke Brunkhorst: Taj je model zastario. Znanstvenici i drugi umjetnici, ali i oni koji su profesionalni zabavljači, političari ili općenito novinari mogu jednako kao i pisci djelovati kao intelektualci.

Američki su intelektualci oko časopisa Partisan Review često isticali kako "pravi” intelektualac nije zaveden mainstream kulturom svojega vremena. Je li to i danas prema Vama jedna bitna odrednica intelektualca?

Dietz Bering: To što su oni tražili u principu je bilo pravilno. I moja definicija intelektualca sadrži tu misao, u samoj formuli: on je sudionik, ali ne i pripadnik nečega. Teško se može poreći da današnji mainstream sačinjava neoliberalna gramzljivost prema industriji. Jasno je da se zato intelektualci posebno trude ne pripadati takvoj skupini. Jer opisana skupina prije svega traži pobornike koji nisu u stanju održati bilo kakav kritički odmak.

Nathan Glazer: Intelektualci često odbijaju mainstream kulturu njihova vremena, no u posljednjim desetljećima sve se više i više prihvaćaju aspekti suvremene mainstream kulture. Sjećam se iznenađujućeg članka koji sam pročitao u Partisan Reviewu - mora da je to bilo prije 50 godina - o Beatlesima, koji je, mislim, napisao Robert Poirier. Christopher Ricks napisao je knjigu o Bobu Dylanu. Čvrsto izražene granice koje su između 1930-ih pa do 1949. u Sjedinjenim Državama oblikovali intelektualci poput Dwighta Macdonalda ili Clementa Greenberga, dakle granice između "visoke kulture", "kulture srednje struje" i "šund" kulture, uglavnom su probijene, kao što je, primjerice, slučaj sa jazzom.

Hauke Brunkhorst: Ne. Mislim da je takav stav pogrešan i elitistički. No, naravno, pritom ne želim reći da se manjinske, potpuno obilazne ili radikalne pozicije ne trebaju pojavljivati. Baš naprotiv.

Kako gledate na odnos intelektualaca i umjetnika? Ponekad se oni poistovjećuju, smatrajući da, unatoč izuzetnim vještinama koje posjeduju, ni jedini ni drugi ne pružaju društvu praktičku korist u svakodnevnom smislu. Slažete li se s time?

Carol Becker: $\mathrm{Ne}$, ne mogu se $s$ time složiti. I ne znam što bi "praktička korist" značila. Umjetnici posjeduju toliko važnih vještina koje su primjenjive u brojnim različitim situacijama, ako se uključuju u rasprave. Oni rješavaju probleme prostorne/vremenske dimenzije. Oni shvaćaju ljudske osjećaje, što na ljude utječe, što ih pokreće. Naravno, veliki je problem društva što se umjetnici ne uključuju dovoljno u oblikovanje urbanih krajolika, rješavanje pitanja oblika ili shvaćanje ljudskih tegoba. Genijalna je bila ideja zamoliti slavnog redatelja Wernera Herzoga da snimi dokumentarni film o pisanju SMS 
poruka i vožnji, dakle o svim nesrećama i smrtima koje su na taj način prouzročene. To je doista bilo briljantno. Zašto ne upitati naše najbolje umjetnike da pomognu u rješavanju društvenih problema, i to kroz njihov način rada? Zašto ne tražiti od velikih filmaša da obrađuju ozbiljna pitanja? Oni znaju kako dodirnuti ljude i prikazati osjećaje. Jednostavno ih ne koristimo dovoljno.

Ako govorimo o vizualnim umjetnicima, rekla bih da oni rade na različit način od intelektualaca. Oni uglavnom rade preko slika, metafora ili pokreta. Često jezik nije njihov način djelovanja. A ako je riječ o pjesnicima, piscima itd., oni ne moraju nužno raspravljati o svojim poantama kao što to čine često intelektualci, već ih demonstriraju pomoću različitih medija. Intelektualci svijet sagledavaju analitički. Većina umjetnika svijet gleda metaforički. U tome leži razlika.

Carlo Bernardini: Intelektualci i umjetnici često su povezani, ali pripadaju svijetu kulture, području koje je često izvan državnoga političkog upravljanja. Državom upravljaju birokrati koji odgovaraju na zapovijedi trećim osobama; društvom se manipulira u službi gospodarstva, a kultura se u tome nalazi na posljednjemu mjestu.

Gerhard Ruiss: I umjetnici i intelektualci traže ili upućuju na nešto što je ispod površine očitog. Vrijedi to čak i u dekorativnoj umjetnosti, koja prelama funkcionalnost i usmjerava pozornost prema nečemu što je dodatno. No, društvu nedostaje svijest o vrijednosti tih postignuća. U stvarnosti društvo neprestano profitira s tim umjetničkim i intelektualnim postignućima, no ne želi im udijeliti veće uloge. Koliko god je društvo usmjereno na korisnost, čista korist može biti cilj tek unutar nekoliko godina, a ne dulje, jer se društvo uvijek ponovno okreće veličanstvenim građevinama, nadilazeći funkcije u potrazi za reprezentacijom, imenovanjima i opisima.

\section{Kako ocjenjujete ulogu društvenih znanosti danas te napose modernih teorija u znano- stima kao što su povijest ili lingvistika? Mislite li da teoretičar s pojedinog područja mora biti svjestan ne samo stručne već i javne odgovornosti-dakle brinuti o tome da svoju tezu predstavlja široj javnosti?}

Henry A. Giroux: Društvene su znanosti suviše instrumentalizirane, lišene kritičkih vokacija, one su sada u velikoj mjeri sredstvo korporativnih i vojnih interesa. Vrve stručnjacima i prikupljačima podataka koji nisu ništa više od državnih službenika. To je područje izgubilo svoj identitet kao izvor učenosti koja je usmjerena prema javnom dobru. Odstupanje od demokratskih vrijednosti i svih prihvatljivih pristupa koji zagovaraju zajedničko dobro dogodilo se uglavnom zbog sve veće korporatizacije sveučilišta s jedne strane te usponom privatiziranih fondacija koje financiraju poduzeća s druge strane. U njima se razvijaju vlastiti stručnjaci na području društvenih znanosti, koji djeluju uglavnom kao antijavni intelektualci i nekritička piskarala. Kada još k tomu na visoko školstvo utječu neoliberalni modusi uprave, fakulteti postaju reducirani uglavnom na "part-time" i privremeni rad, a boje se kritički istupati u javnosti jer mogu izgubiti posao. Također, mislim da je profesionalizacija koja određena područja pokreće, pa tako i društvene znanosti, dovela do toga da su te struke zapele unutar određenih oblika žargona i posebnih načina izražavanja koji razumije vrlo ograničen broj ljudi. Na taj je način zaustavljen razvoj zdravorazumskog osjećaja prema vokaciji intelektualaca i potreba da se intelektualci bave problemom ljudske patnje, da brinu o odgovornosti sile i da tumače, propituju $\mathrm{i}$ ispituju autoritet umjesto da mu podliježu. 
Od 1980-ih godina do danas na tržištu postoji gotovo bezbroj knjiga s dramatičnim naslovima poput The Last Intellectuals (1987.), Public Intellectuals: A Study of Decline (2001.) ili Public Intellectuals: An Endangered Species (2006.). Śto mislite da je dovelo do toga da se u posljednjim desetljećima govori toliko o nestanku, marginalizaciji, proliferaciji intelektualaca koji kao da su jednostavno "pogubljeni medu fakultetima" (Russell Jacoby, 1987.)? Kako danas gledate na položaj javno prisutnih intelektualaca?

Steve Fuller: Iako u tim djelima postoje vrlo zanimljive opservacije, po meni je čitav taj žanr podosta nekonzekventan. Intelektualci oplakuju "opadanje intelektualnog života" tijekom čitave povijesti tog koncepta. Djelo Juliena Bende La trahison des clercs (1927.) u tom je nizu jedno od najdostojanstvenijih i samosvjesno napisanih djela. Benda je shvatio da ga iskonski nije smetao manjak respekta koji intelektualci uživaju u društvu, već demokratizacija kulture koja je dovela do toga da su intelektualci izgubili svoje temelje (kako je on tvrdio). Engleski ekvivalent toj knjizi moguće je pronaći kod Allana Blooma, tj. njegova djela Closing of the American Mind (1987.). Ne iznenađuje da su i Benda i Bloom bili platonisti. No, ta nit nije više toliko očita u novijim djelima toga žanra, $s$ obzirom na to da autori barem nominalno tvrde da su povezani $s$ javnom sferom (a neki se, poput Russella Jacobyja, i dalje smatraju "ljevičarima"), unatoč tomu što ne sudjeluju $\mathrm{u}$ de facto intelektualnim prosudbama te javne sfere. U tom smislu žanr ima lošu sudbi$\mathrm{nu}$, jer ne priznaje vlastite antidemokratske impulse. Pravi je skandal javnog života intelektualaca to što intelektualci koji zagovaraju demokraciju nisu u stanju izvesti učinkovitu nenasilnu političku revoluciju. Iako u posljednje vrijeme možemo možda istaknuti primjer Čehoslovačke, radi se ipak o iznimci. U općenitom smislu takve je pokušaje uglavnom obilježio neuspjeh. O tome je pisao Charles Kurzman u Democracy Denied (2008.), promatrajući Kinu, Rusiju, Meksiko, Tursku, Iran i Portugal u godinama uoči Prvoga svjetskog rata, dakle u razdoblju kada su svi pokušaji međusobnog umrežavanja različitih grupa ambicioznih intelektualaca sa zapadom propali. Dok god je mač snažniji od pera, barem u praksi, umanjena uloga intelektualaca djelovat će opravdanom.

Gerhard Ruiss: Sva ta proročanstva govore isto, da je došlo do smjene ili da smjena uskoro dolazi. A mi već neko vrijeme živimo u tom stanju smjene, bez prave propasti. Opet postoje desni filozofi, koji ranije u društvu nisu mogli niti pronaći mjesto niti skretati na sebe pažnju, postoji niz intelektualnih pratioca koji su ranije sami vlastito postojanje zabranjivali, a s obzirom na to da govor može bitno utjecati na tržišne šanse, zavladala je i nova šutnja. Doduše, još ne postoje osobni savjetnici intelektualaca, ali već su tu agenti koji im govore što je dobro kada pišu knjige ili nastupaju i što trebaju prenositi u svojim djelima i nastupima, kako si ne bi pokvarili karijeru.

Američki filozof Richard Rorty jednom je prilikom rekao da je filozofija, odnosno sva intelektualna bića, "dio razgovora koji sami činimo". Smatrate li da se u današnje vrijeme sugovornik intelektualaca, društvo, u bitnom smislu promijenio u usporedbi s vremenom od prije 10, 20 ili višse godina? Mislite li da današnji intelektualci, kada govorimo o njihovu javnom istupanju, imaju, dakle, bitno drugačiju ulogu nego nekoliko desetljeća prije?

Pierpaolo Antonello: Javlja se jedan teorijski trend koji naglašava odnose, diskusije i horizontalnu izmjenu unutar društvenih skupina, mreža i drugih određenih područja, kao nov način pomoću kojega intelektualci učinkovitije društveno djeluju, naglašavajući 
demokratičniji pristup kulturnim i ideološkim formama koji je "odozdo". Pierre Bourdieu napisao je da trebamo travailler à une invention collective des structures collectives d'invention qui feront naitre un nouveau mouvement social, c'est-à-dire des nouveaux contenus, des nouveaux buts et des nouveaux moyen internationaux d'action. $\mathrm{U}$ tom smislu društvo nije izravno u dijalogu s intelektualcem, već je on jednostavno dio različitih mreža koje čine društvo. Ne možemo se nadati utjecaju, već samo određenom obliku suradnje u definiranju zajedničkog jezika i ideja.

Henry A. Giroux: Javni su se intelektualci još od 1970-ih godina našli na udaru, posebno u Sjedinjenim Državama. Neslaganje ipak nije izjednačeno s pojmom "neamerički" ili s izdajom, kao u slučaju Edwarda Snowdena ili Bradleyja Manninga. Međutim, također mi se čini da neoliberalno normalizacijsko i antiintelektualističko stanje potkopava javne sfere i formativne kulture koje su inače sposobne i ključne u stvaranju javnih intelektualaca. Radi se o visokom obrazovanju, kulturnoj industriji i drugim ključnim javnim sferama koje su uvelike komercijalizirane, podčinjene imperativima kazinskog kapitalizma koji intelektualce shvaća samo kao službenike države ili korporacija. Tomu se još dodaje ideološka i strukturalna kriza s kojom su suočeni intelektualci i pojava nove elektroničke tehnologije koja pomaže pomanjkanju kritičke misli i građanske pismenosti, te na taj način dodatno otežava da pojedinac razmišlja kritički i s određenom mjerom građanske hrabrosti. Intelektualcima je postalo prejednostavno prodavati svoje proizvode velikim bankama, financijskim službama i drugim korporativnim mastodontima koji kontroliraju glavne institucije u većini zapadnih društava.

Pierre Bourdieu govorio je o opasnostima s kojima intelektualca suočava televizija, s potrebama žurnalizacije intelektualne misli i pojavom televizijskih znalaca - tzv. Le Fast Talker. Kako gledate na odnos intelektualca $i$ televizije, $i$ nadalje odnos intelektualca $i$ interneta?

Dietz Bering: Televizija se sve više i više svodi na fast food. A upravo bi se na taj način čovjeka trebalo prikovati za trivijalno fasciniranje, dakle prikovati ga za suprotno od onoga što zastupa intelektualac. Treba spriječiti razmišljanje - a slično djeluje, iako vidno slabije, i internet. Internet stvara privid da se čistim zbrajanjem činjenica dolazi do rezultata i stajališta koje je moguće zastupati. Međutim, činjenice i važnost tih činjenica koju dobivamo vrednovanjem njihove težine i njihovih principa - to su dvije jasno različite stvari.

Simon Sheikh: Stilistički pristup te privatizacija i komercijalizacija televizije doista ostavljaju malo ili nimalo prostora za tradicionalnu dogmatiku intelektualca - pa u tom smislu i Bourdieu ima pravo. Međutim, internet pruža drugačiji način komunikacije i cirkulacije, otvara potencijal masovne intelektualnosti. No, kao i uvijek, društvo kontrole uzvraća udarac, u ovome slučaju u obliku takozvanih društvenih medija.

Boris Vezjak: Jedina opasnost, koju vidim, nalazi se u instantizaciji poruka, senzacionalističkoj manipulaciji, tabloidnoj jednodimenzionalizaciji sadržaja. Ne vjerujem da televizija kao medij zbog svojih specifičnosti stvara prepreke sui generis - opasnost se nalazi u žurnalističkom pristupu.

Pierpaolo Antonello: Između televizije i intelektualaca sve je više osjećaja indiferentnosti; televiziju neki i dalje koriste u svrhu samopromocije, no televizija je zastarjeli medij. Internet je nova platforma političkih, društvenih i kulturnih diskusija; baš kao i u smislu 
zabave ili izvora informacije. Utjecaj interneta ne shvaća se još u cijelosti, no to je sasvim sigurno agora 21. stoljeća.

Steve Fuller: Bourdieuova pristranost u stavu protiv televizije odaje nam vrijeme iz kojega dolazi. On je odrastao prije negoli je televizija postala sveprisutna. Intelektualni život oduvijek je pozitivno vrednovao brzi govor. Pritom se taj govor izjednačuje s dosjetljivošću, pojmom koji je zaživio tek u doba prosvjetiteljstva. Dosjetljivost je usko vezana uz silogizme i ovladavanje njihovim korištenjem, prilikom čega netko jasno izriče zaključak (možda i premisu radi retoričke uvjerljivosti), a slušatelj može sam doći do impliciranog argumenta. Dosjetljivost olakšava dodatna vizualna maštovitost jer, kako kažu Kinezi, slika govori tisuću riječi. Da budemo točni, dosjetljivost je moguće promatrati i unutar elitističkih i unutar proleterskih obrazaca. Na razini elite to je kada unutar rasprave nisu jasno izraženi međukoraci, što na publiku djeluje zbunjujuće i zagonetno. No, u proleterskom smislu dosjetljivost može razjasniti opće prepoznatu istinu i objasniti zašto je istinita, a da se pritom ne uloži previše vremena ili puno raspravljanja. Još treba ozbiljnije obraditi psihologiju koja se nalazi podno te dosjetljivosti (iako je Freud o tome imao mišljenje), uključujući i preklapanje kratkih, ali oštrih emocionalnih izljeva unutar inače emocionalno neutralnog rezoniranja, nešto što televizija ritualizira kada se puštaju snimke smijeha i pljeska.

Gerhard Ruiss: Tko se želi pojavljivati, mora se držati medijskih zakonitosti, tko se ne drži medijskih zakonitosti, ne pojavljuje se - to je jednostavna formula prema kojoj se sve što ima veze s medijima orijentira. Mediji, a posebice televizija, dopuštaju samo ključne, udarne rečenice - dakle, tko pokušava nešto produbljivati, tamo se zasigurno neće naći. Interesantno je da intelektualci, za razliku od odnosa prema televiziji, danas pokazuju određenu rezervu kada je u pitanju internet. Intelektualci su u televiziju još vjerovali, mislili su da se njome dotiču mase, no od interneta se to zasad ne očekuje. Nije baš moguće primijetiti euforiju intelektualaca prema internetu. $\mathrm{Na}$ to se gleda uglavnom kao na sredstvo koje olakšava komunikaciju i dostavu.

Henry A. Giroux: Mislim da mediji koji danas diktiraju, u svim svojim manifestacijama - od novina, radija, televizije i filma - ostavljaju vrlo malo prostora za kritiku, sadržajni dijalog i prosudbu. Navedeni su mediji uključeni u ono što Chomsky naziva "proizvodnjom pristanka" (manufactured consent), u proizvodnju spektakla nasilja, promovirajući kulturu "celebrityja" koja je postala dominantni model funkcioniranja unutar gasećeg modusa potrošnje. Ograničen broj mega-korporacija upravlja tim dominantnim medijima koji mjesto ustupaju "brzim intelektualcima", kako ih je Bourdieu nazivao. Radi se često o drugorazrednim naučnicima ili idiotskim sveznalicama, koji tržište pune sloganima i odgovorima koji su u trendu, a baš nikoga ne iznenađuju. Značaj je tih poruka povećati gledanost. Takvi su brzi intelektualci odani slavi, novcu i autoritetu, dok im istina, osjećaj društvene odgovornosti ili predanost i strast za stvaranje pravednijeg svijeta ne predstavljaju mnogo. Takvi intelektualci javni život ne obogaćuju, već ga, naprotiv, degradiraju. No istovremeno, u doba digitalnih i elektronskih medija, kada se platforme komunikacije i kulture ekrana šire, javni intelektualci prvi put od 1970-ih godina imaju priliku proširiti svoju publiku i uključiti se u kritički angažman, što je izuzetno važno za sudbinu svih civiliziranih demokratskih društava. Javni intelektualci trebaju svim mogućim sredstvima propitivati vokabulare, institucije, ideologije, vrijednosti koje stvaraju neoliberalizam i druge autoritarne sile rata, nasilja i privatizacije koje prijete Zemlji. 
Novi mediji otvaraju prostor i priliku da se intelektualci uključe u novi utopistički diskurs, unutar kojega se buduće društvene promjene mogu zamisliti isključivo kroz uvjete koji ne oponašaju sadašnjost. Javni intelektualci trebaju ukloniti sve tragove sekretarstva, političkog purizma, moralnog apsolutizma. Moraju se angažirati kroz samokritičnost, na način da su u stanju saslušati druge i spremni pokazati ono što je Orwell nazivao rijetkom moralnom i političkom ljepotom "uvredljivosti" istine, da su spremni upozoriti na odgovornosti moći i autoriteta. To ne bi trebala biti osnova pomoću koje možemo zamisliti bolji svijet, već i način na koji se kolektivno za takav svijet borimo.

\section{Još je Jean-François Lyotard (1988.) upozoravao kako univerzalni autoritet intelektualca u današnjem vremenu nestaje. Što za Vas znači takvo segmentiranje znanja $i$ stvaranje sve užih stručnjaka za najrazličitija područja unutar struke?}

Hauke Brunkhorst: Prvo, ne mogu reći da je došlo do krize kritičkog ili angažiranog pisanja ili govora. Diljem svijeta dovoljno je kritičke i popularne inteligencije. Lyotard i ima i nema pravo. U pravu je jer su autoritet intelektualci izgubili, a ne bi ga ni trebali imati. Čak se i novi Papa udaljava od modela autoriteta koji je već skoro dva tisućljeća bio osnovica Crkve, djelujući kao obični intelektualac. Tko danas nastupa u javnosti, mora se oprostiti od svake svetosti ili svakog autoriteta koji ostaju u Crkvi. I to je veliki napredak. No, i u tome Lyotard griješi; pritom onaj tko nastupa u javnosti ne odustaje nužno od univerzalne istine. To je nemoguće $i$, da on ili ona to žele, ne bi bilo ostvarivo. Univerzalna istina, javna komunikacija i demokracija tvore do danas neraskidivu poveznicu. Demokracija bez istine bila bi kao demokracija s autoritetom. Istina je, kao i demokracija, suprotna autoritetu.

Gerhard Ruiss: Klasičnog je intelektualca danas izuzetno teško pronaći, čak se i među nekadašnjim kritičkim intelektualcima pronađu oni koji ne skrivaju opčinjenost militarističkih opcija, dakle nešto što je za klasično angažiranog intelektualca nepojmljivo. Preostali su nam eksperti i komentatori, koji ono što imaju pred sobom smisleno oblikuju, ali koji nemaju smisao za širi vremenski i društveni kontekst. Intelektualni su diskursi postali stručni diskursi, odvojeni od općih diskursa koji su potonuli na razinu pukog pričanja.

Dietz Bering: Doista, sveučilišta su osuđena (bez ikakve mogućnosti obrane!) na to da putove studentske naobrazbe (bakalaureat, master) usmjeruju tako da se svi pretvaraju kao da je jedini preduvjet za uključivanje u realnost, dakle sveprisutne industrije ili uslužne kompanije, znanje iz ograničenih sektora, dok se pritom realnost toliko brzo izmjenjuje da se praksa može stjecati isključivo na licu mjesta. Na taj način gubi se i jedno i drugo: 1) realističko shvaćanje prakse i 2) temeljni kritički stav i u općenitom smislu stasanje generacija studenata (= predestinirani intelektualci). To znači: sveučilište je pogospodarstveno, iako bi trebalo težiti obrazovanju putem znanosti.

Steve Fuller: Unutar uobičajenih načina društvene reprodukcije intelektualci su oduvijek bili marginalni. Zapravo, Joseph Schumpeter s određenim je sarkazmom objasnio uspon intelektualaca kao "sigurnosni ventil" koji ispuhuje paru kada se kapitalistički stroj počinje pregrijavati. U svakom slučaju, intelektualci kao sloj djeluju snažnima, samo zato, da se poslužim engleskom metaforom iz boksa, što "se bore iznad svoje kategorije”. Specijalizacija znanja nije promijenila taj opći fenomen, no ona je umanjila ulogu 
humanista kao intelektualaca. Dovoljno je navesti jednostavan primjer. Ako pošaljete vaše mišljenje u The New York Times, pitaju vas za ekspertizu koju vašim tekstom doprinosite odabranoj temi, što zauzvrat pomaže pri odluci hoće li se vaš prilog objaviti. Drugim riječima, akademski autoritet "intelektualca" vrlo je blisko povezan $s$ istraživačkim radom, od kojega se očekuje da daje oblik znanja i uvida koji drugi nemaju. To što novine humanistima pristupaju na tako ograničen način, u velikoj je mjeri problem samih sveučilišta: cijena je ekspertize za humaniste da u javnoj raspravi ostaju skučeni unutar uskog područja relevantnosti.

Boris Vezjak: Mogu vam reći za Sloveniju, a vjerojatno i šire: sveučilišni autoritet nestaje jer profesori i istraživači sa sveučilišta nemaju više vremena baviti se društvenim problemima. To je inače samo jedan od najvažnijih razloga. Zahtjevi akademskog života kvantificirani su, akademičari trče da sakupljaju bodove za svoje habilitacije, što postaje teže i teže. Akademski život donosi neku vrstu deintelektualizacije, odmak od kritičkog angažmana. Inače se slažem i s Lyotardom, zahtjevi za specijalizacijom u svojemu području imaju za posljedicu fragmentaciju znanja, a intelektualac treba širu sliku društvenog zbivanja, koja se time gubi.

Kako Vi gledate na odnos suvremenog intelektualca $i$ računala, računalne znanosti $i$ inteligencije? Je li to, prema Vama, jedna komponenta modernog intelektualca ili, upravo suprotno, moderni intelektualac pruža otpor prema samom konceptu računala-dakle inteligencije svedene na norme, varijable i datosti?

Hauke Brunkhorst: Upravo pišem na računalu, a naš je odnos unatoč tomu dosta egalitaran i demokratičan. Ja računalo ne mogu pročitati niti ono može mene, kada mu dajem naredbe, često me odbija, pa bih vjerojatno trebao reći da slijedi samo one naredbe koje želi slijediti. Naravno, postoje velike razlike, ali nisu mnogo veće od onih između nas i velikih majmuna. Budući da je komunikacija (računala i intelektualca) sve češća i da dolazi i do intelektualne razmjene, s napetošću možemo iščekivati što će sve dalje moći naučiti. To bi moglo demokraciju kakva je nama poznata temeljno promijeniti, no možda i ne.

Dietz Bering: Meni su računala samo pomoćno sredstvo. Međutim, ona mijenjaju stanje problema, jer intelektualac danas u mnogo manjoj mjeri predstavlja "ono što znamo". Znanje je sada postalo dostupno svima - bez mnogo truda. Baš stoga moralne odlike intelektualca dolaze na vidjelo: intelektualac nije iziritiran poplavom znanja, već mislima povezuje u jedno te potom donosi prosudbu koja ima moralne temelje.

Steve Fuller: Intelektualcu širenje računala ne bi trebalo predstavljati problem, jer se u krajnjoj liniji zadaća intelektualca svodi više na prosudbu, a ne na sam proces mišljenja. Ustvari, računala mogu biti izuzetno korisna jer intelektualcu pružaju različite stavove koje je potrebno razmotriti prije negoli se donosi prosuda, koju naposljetku donosi intelektualac. Isplati se prisjetiti da je tijekom prosvjetiteljstva javna uloga intelektualca (“javna korist razuma”, kako je Kant govorio) bila dokazati da postoji kapacitet za prosudbe koje se mogu donijeti unatoć konkretnim posljedicama, ako ih uopće i ima (uglavnom nije bilo posljedica jer većina odraslih muškaraca nije još imala pravo glasa). Ipak, odu li intelektualci toliko daleko da prihvate "postmoderna" stajališta kojima se jednostavno prikazuju sve strane problema bez da se donose prosudbe, ulazimo u rizik 
da nas računala zamijene. Računala su odlična kada su u pitanju kompleksnost i ambivalentnost.

Kako osobno gledate na umjetnu inteligenciju naspram one "klasične", dakle ljudske? Osnovu ljudske znanosti i filozofije - neki bi rekli i inteligencije - u staroj Grčkoj predstavljale su logika i matematika. Upravo logika i matematika čine bitne temelje razvoja istraživanja umjetne inteligencije, koja sada pokušava postići tjelesni (korporalni) oblik. Kako Vi promatrate odnos umjetne inteligencije i ljudske inteligencije?

Steve Fuller: Slažem se, moderno shvaćanje inteligencije ima svoju osnovu u matematičkom rezonu koji se shvaća kao osnova logike. To bi u staroj Grčkoj vjerojatno djelovalo dosta ekstremno, uglavnom bi se povezivalo s pitagorejcima i platonistima. Naravno, ljudska su bića mnogo više od samo čiste inteligencije, no ako govorimo o samoj inteligenciji, to je ipak u srži. Za mene je u tom smislu zanimljivo pitanje kako smo došli do toga da (a) je to najznačajnije svojstvo ljudskog postojanja i (b) da to svojstvo možemo reproducirati, ako ne i proširiti, vlastitom kreacijom. Moj je odgovor trajno uvjerenje - i nakon što su vjerski impulsi i opravdanja iščeznuli - u platonskom čitanju biblijske tvrdnje da smo stvoreni "na sliku i priliku Božju”. Drugim riječima, ljudi su ujedno i poput bogova i nepotpuni bogovi. Dakle, nalaže se vrsta koja će prethoditi (možda stvorena umjetno), koja je u stanju pojačati naše shvaćanje Boga, a čiji se dosezi definiraju univerzalnim. Matematika nam omogućava najjasniji pristup konačnoj koncepciji bića, jer nas vodi prema ideji beskonačnosti. To su temelji unutar kojih nije nerazumna ni želja da vlastite kapacitete, one bogovske, upotrijebimo i stvorimo bića koja mogu mnogo bolje dostizati tu univerzalnost. Nije vjerojatno slučajno da su se Isaac Newton, George Boole, Norbert Wiener, Herbert Simon i Ray Kurzweil, svi redom, smatrali “unitaristima”, kršćanskom herezom koja najeksplicitnije izdvaja ljudsku nasljednu božansku prirodu.

Nathan Glazer: Po tom se pitanju držim onoga što govore filozof John Searle i njegovi sljedbenici. Umjetna inteligencija, odgovori koje nam pruža računalo, koliko god komplicirani i ingeniozni bili, ipak nisu ljudska inteligencija.

\section{Kako onda prema Vašem sudu tehnologija utječe na intelektualni svijet danas?}

Pierpaolo Antonello: Poznato nam je da je suvremeni intelektualac povezan s pojavom tiska, tako da tehnologija proizvodi i oblikuje način na koji mi proizvodimo i širimo ideje. Manuel Castells provodi zanimljiva terenska istraživanja na tom području, naglašavajući zaobilaženje bilo kojeg oblika vertikalnog, autoritativnog posredovanja (što je tradicionalni opis uloge intelektualca), koje pritom ne znači gubitak političke ili društvene djelatnosti. Prema Catellsu, društvene se promjene mogu poticati razgovorom koji uključuje povezivanje mreža i neuronskih mreža. U tehnološkom i morfološkom smislu taj oblik mrežne komunikacije pokreće proces mobilizacije, tvoreći istovremeno i sam proces i njegov konačni ishod. Internetske društvene mreže su horizontalne i selektivne, pa na taj način stvaraju osjećaj povjerenja i solidarnosti među njihovim pobornicima. Budući da su neposredni u odnosu na formalne oblike vodstva koje je pogodila kriza legitimiteta (i kod političara i kod tradicionalnih intelektualaca), stvaraju simulaciju suradnje i recipročnosti. Nemoguće ih je kontrolirati jer ne postoji njihovo središte, a mreže se rekonfiguriraju do u beskonačnost. One su istovremeno i lokalne i globalne, 
samoreflektivne. Oblikuju javni prostor, i u gradskom prostoru i u prostoru cyberspacea, gdje su uključene u trajnu raspravu. Međutim, društvene mreže ne mogu preuzeti oblik bilo kakve organizacije ili vodstva, s obzirom na to da krajnji doseg konsenzusa koji se postiže ovisi o ad hoc diskusiji i protestu, a ne o programu i specifičnim ciljevima. Prema tome, među njima nema fokusa na određene zadatke ili projekte, jer ih je nemoguće bitno usmjeravati u političkom smislu. Političke stranke (kojima se ne vjeruje) nisu u mogućnost kooptirati društvene mreže, iako stranke mogu profitirati u promjeni javnog mnijenja na koje mreže utječu. Ipak, postoje društveni pokreti koji mijenjaju društvene vrijednosti, a da su pritom ujedno i pokreti javnog mnijenja (kod izbora), pa su u tom smislu također i oblici političke pobune. Iako se zalažu za demokraciju i reprezentaciju, takvi pokreti nisu programatske naravi ni svrhoviti. Oni žele preoblikovati državu, a da je pritom ne preuzmu. Izražavaju određene osjećaje i potiču rasprave, ali ne stvaraju stranke ili se priključuju vlasti - iako postaju meta političkog marketinga. No, s druge strane, $\mathrm{u}$ jednom fundamentalnom smislu izuzetno su politički usmjereni kada nude i prakticiraju izravnu, deliberativnu demokraciju koja se temelji na mrežnoj demokraciji.

Boris Vezjak: Veoma pozitivno. Poznat sam kao žestok kritičar slovenskih medija i novinarskih postupaka, zbog čega sam često cenzuriran u svemu što radim, a pogotovo u medijskoj kritici. Moja kritika medija zapravo rezultira u mojoj intelektualni izolaciji. Nema puno mjesta gdje mogu objavljivati i biti angažiran. Zbog toga sam i prešao na blog na Facebooku, kojem sam se inače u početku protivio. Tehnologija i internet mi, znači, omogućavaju da još ostajem intelektualac kao cyber dissident. Ima li još neki bolji dokaz u korist tehnologije?

Steve Fuller: Najočitiji odgovor bio bi da tehnologija daje širem krugu ljudi mogućnost da djeluju kao intelektualci i istovremeno otežava da se intelektualac shvaća ozbiljno, što je zaslužio. Iako se to kao problem prepoznalo još u početnim danima tiska, razvile su se relevantne diskriminacijske sile. Zato sam u tom pogledu sangvinik. Čini mi se da je veći problem, kada se bavimo specifično internetom, to da se nekoga proglašava "intelektualcem" samo zato što informacije pušta u javnost, a da pritom ne nudi nikakvu posebnu interpretaciju, osim možda nedefinirano prijetećeg stava. More ispuštenih podataka potom nudi i skrovište. Razmotrimo radikalnu razliku između djela pragmatičnog intelektualca suvremenog doba, Émilea Zole, i Juliana Assangea, osnivača Wikileaksa. Zolin J'accuse temelji se na čitanju transkripta sa suđenja kapetanu Dreyfusu, pomoću kojega je došao do zaključka da se radi o namještaljci francuskog ureda za vanjske poslove. S druge strane, Assange je jednostavno hakirao diplomatske internetske stranice diljem svijeta i informacije poslao novinarima da s time čine što god žele. Zola se svojedobno nazivao izdajnikom jer je eksplicitno nastojao potkopati autoritet države. Iako se Assangea trenutno tereti za slične stvari, on je ustvari kriv općenito gledano samo za određen nestašluk. Dok je Zola iskoristio vlastiti autoritet kako bi nadoknadio nedostatak pravih dokaza koji bi oslobodio Dreyfusa, Assange se jednostavno skriva iza dokaza, ne želeći preuzeti nikakav autoritet za interpretaciju, očekujući da će taj posao za njega obaviti drugi ljudi. 